\title{
Phytoplankton class determination by microscopic and HPLC-CHEMTAX analyses in the southern Baltic Sea
}

\author{
Elif Eker-Develi ${ }^{*}$, Jean-François Berthon, Dirk van der Linde \\ Joint Research Centre of the European Commission, Institute for Environment and Sustainability, \\ Global Environment Monitoring Unit, TP 272, 21027, Ispra (VA), Italy
}

\begin{abstract}
The contribution of phytoplankton groups to total chlorophyll a (chl a) was derived using CHEMTAX from pigment measurements by HPLC and compared with the carbon (C) biomass estimations obtained from microscopy in the southern Baltic Sea in April 2005. Five different matrices of pigment:chl a input ratios, derived from the literature, were tested. Successive runs of CHEMTAX showed peridinin:chl a for dinoflagellates and fucoxanthin:chl a for diatoms to converge at $0.452 \pm$ 0.02 (mean \pm SD) and $0.489 \pm 0.03$, respectively, with initial ratios varying by a factor of 2 to 3 across matrices. The 2 techniques were in relatively good agreement for the dominant phytoplankton groups. Peridinin, diadinoxanthin, chlorophylls $c_{1}$ and $C_{2}$ (here grouped together as chl $C_{1}+C_{2}$ ), fucoxanthin and alloxanthin were the principal accessory pigments; dinoflagellates, diatoms and cryptophytes were the groups forming the majority of the $\mathrm{C}$ biomass. Diadinoxanthin and chl $C_{1}+C_{2}$ were mainly associated with the dominant dinoflagellates rather than with other phytoplankton classes. Excluding cyanophytes, the correlation between carbon biomass of other minor phytoplankton groups and their chl a was either poor or not significant due to uncertainties in either microscopic counts or CHEMTAX classification. There was a good correlation between carbon biomass of phytoplankton and chl a. The estimated C:chl a ratio of total phytoplankton varied between 8 and 40 (in average $20 \pm 7$ ), with a higher value for dinoflagellates $(30 \pm 17)$ than for diatoms $(9 \pm 7)$. Fucoxanthin-containing small flagellates might have led to the overestimation of the diatom contribution by CHEMTAX at a few stations.
\end{abstract}

KEY WORDS: CHEMTAX $\cdot$ Pigments $\cdot$ Phytoplankton carbon $\cdot$ C:chl a $\cdot$ Baltic Sea Resale or republication not permitted without written consent of the publisher

\section{INTRODUCTION}

Quantifying the variations in phytoplankton biomass and taxonomic composition is relevant for the evaluation of ecosystem function and status, as well as for the study of global biogeochemical cycles. The retrieval of main phytoplankton groups from ocean colour satellite data is also an important input for primary production models operating at the global scale (Alvain et al. 2005, Uitz et al. 2006), as photosynthetic parameters may vary according to taxonomic composition. Traditionally, phytoplankton groups are quantified under light microscope by identifying and counting cells, measur- ing their size, and converting the resulting volumes $(\mathrm{V})$ to carbon (C) biomass on the basis of previously established equations (Strathmann 1967, Verity et al. 1992, Montagnes \& Franklin 2001). However, depending on the equation chosen for this conversion, calculated $\mathrm{C}$ values may vary for a specific taxonomic group (Havskum et al. 2004, Llewellyn et al. 2005). Moreover, intra-class variations up to $\sim 30$-fold in the C: $V$ ratio of phytoplankton were observed (Llewellyn et al. 2005 and references therein). A more recent method to estimate the distribution of phytoplankton groups is based on the measurement of pigment composition of cells making use of the HPLC technique (Mantoura \& 
Llewellyn 1983, Rodriguez et al. 2002). This technique is faster and more appropriate for the identification of pico- and nano-phytoplankton than the microscope method as complementary to flow-cytometry (Veldhuis \& Kraay 2004). Thus, HPLC has been increasingly used, in particular for the large-scale mapping of pigments and phytoplankton groups in the world oceans (Tester et al. 1995, Vidussi et al. 2001, Llewellyn et al. 2005, Wänstrand \& Snoeijs 2006). Nevertheless, important uncertainties in retrieved phytoplankton composition may result from the variability of the cellular pigment contents due to light and temperature changes, nutrient availability, distinct growth phases, as well as from the preclusion of phycobiliprotein quantification through HPLC. Furthermore, the ambiguous character of some marker pigments (i.e. their being shared by several phytoplankton groups and even by ciliates) in addition to intra-class and interspecies variation of pigment:chlorophyll a (chl a) ratios, are other issues which have to be cautiously considered in pigment studies (Schlüter et al. 2000, Henriksen et al. 2002, Irigoien et al. 2004). Lastly, nonpigmented heterotrophic phytoplankton species cannot be monitored with the HPLC method.

In order to relate the measured pigment composition to the distribution of phytoplankton groups, statistical techniques like multiple linear regression (Tester et al. 1995) or matrix factorization, such as the well known CHEMTAX software (Mackey et al. 1996), can be used. However, simple multiple linear regression analysis has several shortcomings compared to CHEMTAX, such as the occurrence of negative contributions to total chl a (Henriksen et al. 2002 and references therein). CHEMTAX, which uses predefined pigment: chl a ratios, is a powerful and robust approach for the taxonomic classification of phytoplankton assemblages in spite of the limitations related to pigment investigations mentioned above (Mackey et al. 1996, Schlüter et al. 2000, Rodriguez et al. 2002).

The C:chl a ratio of phytoplankton is also highly variable and depends on light, temperature, nutrients and species composition. Values ranging between 10 (Laws \& Bannister 1980) and 250 or more (Cullen 1982, Veldhuis \& Kraay 2004) were reported for natural phytoplankton populations. Several studies reported a good agreement between C biomasses of phytoplankton groups (as derived from microscopic determination) and class-related chl a concentrations (as derived from CHEMTAX analysis) for large diatoms, but a poor conformity for dinoflagellates, prymnesiophytes and small flagellates (Llewellyn et al. 2005 and references therein). This relationship between phytoplankton pigments and $\mathrm{C}$ biomasses of the corresponding taxonomic groups should be further investigated as the results obtained from CHEMTAX analysis might differ according to region, environmental characteristics, phytoplankton composition, or phytoplankton biomass.

The aim of the present work was to investigate the applicability of CHEMTAX to the southern Baltic Sea by using simultaneous microscopic determinations of phytoplankton biomass and HPLC pigment analyses. In particular, the use of the classical Mackey et al. (1996) pigment:chl a input ratios, initially adapted for the open ocean environment, was tested in a highly turbid coastal region, together with other sets of ratios. In this context, validation of a recent study relying on CHEMTAX simulations which allow the use of a priori non-appropriate input ratios (Latasa 2007), was performed. From CHEMTAX and cell-counting results, $\mathrm{C}$ :chl a ratios were derived for total phytoplankton as well as for main groups. These ratios were compared with environmental conditions and simulated ratios obtained from phytoplankton acclimation models (Geider et al. 1997, Blackford et al. 2004).

\section{MATERIALS AND METHODS}

Surface water sampling for pigment and phytoplankton analyses was performed at 31 stations in the southern Baltic Proper between 16 and 29 April 2005, onboard the RV 'Oceania' as a result of a collaboration between the Institute of Oceanography of the Polish Academy of Sciences (IOPAS) and the Joint Research Centre of the European Commission (JRC) (Fig. 1).

Physicochemical and bio-optical measurements. Vertical profiles of temperature and salinity were performed using a Seabird-19 CTD at a depth of $\sim 30 \mathrm{~m}$. The depth of the surface mixed layer $\left(D_{M L}\right)$ was defined as the depth where a change of $>0.3^{\circ} \mathrm{C}$ in temperature over a $5 \mathrm{~m}$ depth interval was observed (Llewellyn et al. 2005).

Underwater and surface radiometric measurements of downwelling irradiance at 7 wavelengths (from 412 to $685 \mathrm{~nm}$ ) were performed with a MiniNess free-fall profiler and surface reference (Satlantic). Above-surface photosynthetically available radiation (PAR) values (in $\mu$ mol photons $\mathrm{m}^{-2} \mathrm{~s}^{-1}$ ) were derived from these measurements and are here referred to as 'irradiance' $(I)$. Average $I$ in the surface mixed layer (SML) was estimated using the equation of Llewellyn et al. (2005) as follows:

$$
I_{\mathrm{SML}}=I_{\mathrm{S}} \mathrm{D}_{50 \%} / \mathrm{D}_{\mathrm{ML}}
$$

where $I_{\mathrm{SML}}$ is average irradiance in $\mathrm{SML}, I_{\mathrm{S}}$ the surface irradiance, and $\mathrm{D}_{50} \%$ the depth at which irradiance was $50 \%$ that of the surface. Optimal C:chl a ratios over the observed range of $I_{\mathrm{SML}}$ and the temperature response factor were derived from models of Blackford et al. 

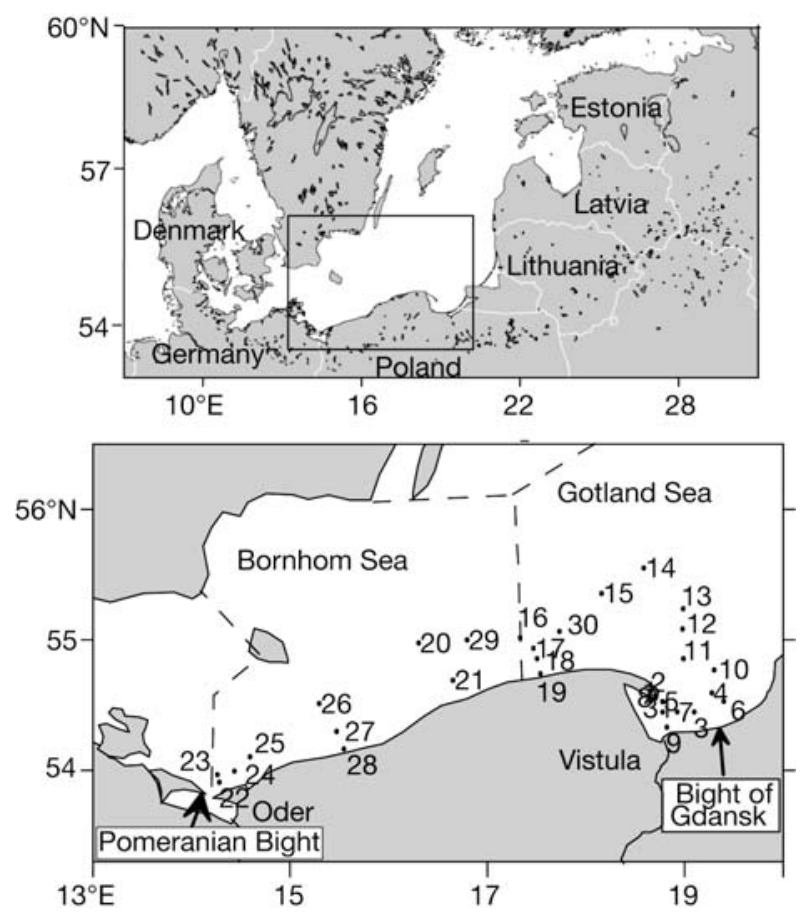

Fig. 1. Phytoplankton and pigment sampling stations in the southern Baltic Proper during April 2005

(2004), which were modified after Geider et al. (1997), assuming the proportion of photosynthate directed towards chlorophyll balances the existing $\mathrm{C}$ :chl a ratio. Initial slope of the photosynthesis-versus-irradiance (P-I) curve, light inhibition of photosynthesis, assimilation rate and maximum $\mathrm{C}$ :chl a ratio were given as $\left.2.98\left(\mathrm{~W} \mathrm{~m}^{-2}\right)^{-1} \mathrm{~d}^{-1}, 0.02(\mathrm{~W} \mathrm{~m})^{-2}\right)^{-1} \mathrm{~d}^{-1}, 1$ to $3 \mathrm{~d}^{-1}$ and 0.075, respectively in this model (Blackford et al. 2004, Llewellyn et al. 2005).

Phytoplankton analysis. Water samples for phytoplankton identification were put into $250 \mathrm{ml}$ amber glass bottles to which a neutral lugol solution was added to obtain a final concentration of $1 \%$. Note that lugol does not allow distinction between phototrophic and heterotrophic flagellates. For the preparation of samples for microscopic analysis, the sedimentation method was used (Eker-Develi et al. 2006a). Samples were concentrated to a $V$ of $\sim 40 \mathrm{ml}$ and the micro- and nanophytoplankton were counted using a Sedgewick-Rafter counting chamber under a phase-contrast binocular microscope. Approximately 400 cells were counted in each sample. The identified species were classified under 8 phytoplankton taxonomic groups: dinoflagellates (Dino), diatoms (Diat), cryptophytes (Crypto), cyanophytes (Cyano), chlorophytes (Chloro), euglenophytes (Eugleno), raphidophytes (Raphido), chrysophytes (Chryso) and small flagellates (sFlag) (Table 1). A few rare prasinophyte species were included in the $\mathrm{C}$ biomass of the Chloro group. Chrysophytes did not include picoplanktonic
Table 1. Abbreviations used throughout this article for phytoplankton groups and photosynthetic pigments

\begin{tabular}{|ll|}
\hline & Abbreviation \\
\hline Phytoplankton & \\
Dinoflagellates & Dino \\
Diatoms & Diat \\
Cryptophytes & Crypto \\
Cyanophytes & Cyano \\
Chlorophytes & Chloro \\
Euglenophytes & Eugleno \\
Raphidophytes & Raphido \\
Chrysophytes & Chryso \\
Small flagellates & sFlag \\
Pigment & \\
Chlorophyll $a$ & Chl a \\
Peridinin & Peri \\
Diadinoxanthin & Ddx \\
Chlorophyll $c$ & Chl $c_{1}+c_{2}$ \\
Fucoxanthin & Fuco \\
Alloxanthin & Allo \\
Chlorophyll $b$ & Chl $b$ \\
$\beta$-carotene & Caro \\
Diatoxanthin & Dtx \\
19'-butanoyloxyfucoxanthin & But \\
Zeaxanthin & Zea \\
19'-hexanoyloxyfucoxanthin & Hex \\
Chlorophyllide $a$ & Chlide $a$ \\
\hline
\end{tabular}

pelagophyceae. Biomass of the phototrophic ciliate Mesodinium rubrum (Lohmann) Jankowski (= Myrionecta rubra) was included in cryptophyte biomass as in previous studies by Henriksen et al. (2002) and Schlüter \& Møhlenberg (2003).

The $V$ of each cell was calculated by measuring its appropriate morphometric characteristics (i.e. diameter, length and width) (Kovala \& Larrance 1966, Olenina et al. 2006). One $\mu \mathrm{m}^{3} V$ was assumed equivalent to 1 pg wet wt (Wasmund et al. 1998, Gasiunaite et al. 2005). For each identified cell, C biomass was calculated from the measured $V$ using the equations of Strathmann (1967) for diatoms (Eq. 2) and other phytoplankton groups (Eq. 3) as follows:

$$
\begin{gathered}
\log C=-0.422+0.758(\log V) \\
\log C=-0.46+0.866(\log V)
\end{gathered}
$$

C biomass of small phytoplankton for cell $V$ (in $\mu^{3}$ ) of $10^{1}, 10^{2}$ and $10^{3}$, was calculated by multiplying these

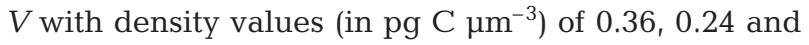
0.16, respectively (Verity et al. 1992). The sFlag group may include chlorophytes, cryptophytes, chrysophytes and (less probably) cyanophytes (the majority of the cyanophytes were colony forming species in the present study) in the size range $\sim 2$ to $20 \mu \mathrm{m}$. C biomass of specific phytoplankton groups (here abbreviated as '[Group]-C') calculated according to Strathmann (1967) were compared with those obtained using equations established by other investigators. In the present 
study, Diat-C calculated from the equations of Montagnes et al. (1994) and Montagnes \& Franklin (2001) was higher than that calculated from Eq. (2) by an average factor of $2.1( \pm 0.2)$ and $1.9( \pm 0.4)$, respectively. The Dino-C found using the equations of Verity et al. (1992) and Menden-Deuer \& Lessard (2000) were higher than values calculated by Eq. (3) by an average factor of $1.2( \pm 0.05)$ while the Dino-C estimated from the equation of Montagnes et al. (1994) was lower by an average factor of $0.9( \pm 0.1)$ than the Cestimated by Eq. (3). When the equations given by Menden-Deuer \& Lessard (2000) for chrysophytes (here applied to small flagellates too) and chlorophytes were used, the total C biomass of these groups decreased by an average factor of $\sim 6(5.5 \pm 1.6)$ with respect to calculations using the equation of Strathmann (1967) which also includes values of Verity et al. (1992) for small phytoplankton noted above. The $\mathrm{C}$ biomass of Mesodinium rubrum was calculated with Eq. (3), as for cryptophytes. However, the C biomass of Mesodinium would double if the conversion factor of Putt \& Stoecker (1989) for oligotrichous ciliates $\left(0.19 \mathrm{pg} \mathrm{pm}^{-3}\right)$ were used.

Pigment analysis. The method used for the HPLC pigment analysis followed the core measurement protocols of the Joint Global Ocean Flux Study (JGOFS 1994), and is a modified version of the method presented by Wright et al. (1991). We collected 0.8 to 61 of seawater and filtered it through $47 \mathrm{~mm} \mathrm{GF/F} \mathrm{Whatman}$ glass fibre filters. The filters were stored in liquid nitrogen for the duration of the cruise and then kept at $-80^{\circ} \mathrm{C}$ until taken to the laboratory for analysis. Each filter was thawed and subsequently transferred into a plastic Falcon tube containing $3 \mathrm{ml}$ of a solution of $100 \%$ acetone and an internal standard; it was then sonicated in a $0^{\circ} \mathrm{C}$ water bath for $1 \mathrm{~min}$ and left to extract for $24 \mathrm{~h}$ at $-20^{\circ} \mathrm{C}$. Extracts were clarified by filtering them onto $0.45 \mu \mathrm{m}$ Teflon syringe filters, and subsequently injected into a Hewlett Packard/ Agilent 1100 HPLC system. The HPLC system used includes a reversed-phase $\mathrm{C}_{18}$ column $(250 \times 4.6 \mathrm{~mm}, 5 \mu \mathrm{m}$ particle size, Hichrom, with a $\mathrm{C}_{18}$ guard column), an autosampler with thermostat, a diode array detector (DAD), a pumping system and degasser, data acquisition and analysis software and a 3 solvent gradient. The 3 solvents were (1) methanol $80 \%$-ammonium acetate (0.5 M) $20 \%$ (2) acetonitrile $90 \%$ and (3) ethyl acetate. The temperature-controlled autosampler (set at $4^{\circ} \mathrm{C}$ ) mixed $75 \mu \mathrm{l}$ of extract with $22.5 \mu \mathrm{l}$ of distilled water buffer before injection through a $100 \mu \mathrm{l}$ loop onto the $\mathrm{C}_{18}$ column. Chromatograms were generated from the absorbance of individual pigments at $436 \mathrm{~nm}$ for chlorophyll pigments and carotenoids, and at $405 \mathrm{~nm}$ for phaeopigments using DAD. The HPLC system was calibrated using pigment standards from DHI Water \& Environment. This method does not permit the separa- tion of divinyl chl $a$ and chlorophyll $b$ (chl $b$ ) from monovinyl chl $a$ and $\operatorname{chl} b$, respectively. It is not capable of fully separating chlorophyll $C_{1}$ and chlorophyll $C_{2}$ (presented here as chl $c_{1}+C_{2}$ ) either. $\beta \gamma, \beta \varepsilon$ and $\beta \beta$ carotenes were not resolved well and their sum was given as $\beta$-carotene. The individual pigments mea-

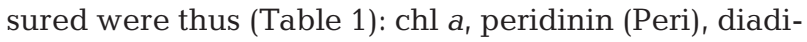
noxanthin (Ddx), chl $C_{1}+C_{2}$ fucoxanthin (Fuco), alloxanthin (Allo), chl $b, \beta$-carotene (Caro), diatoxanthin (Dtx), 19'-butanoyloxyfucoxanthin (But), zeaxanthin (Zea), 19 '-hexanoyloxyfucoxanthin (Hex) and the degradation product of chl $a$, chlorophyllide a (chlide a).

A detailed description of this method and the associated uncertainties is presented in Hooker et al. (2000) and Claustre et al. (2004). Uncertainties on determination of pigment concentrations, defined as absolute percent differences between 4 laboratories (including JRC) were approximately $7 \%$ for the total chl $a$ and $21.5 \%$ on average for the other pigments (ranging from $11.5 \%$ for fucoxanthin to $32.5 \%$ for peridinin).

CHEMTAX processing. The CHEMTAX program (Mackey et al. 1996) was used in order to retrieve the group composition of phytoplankton from some marker pigments. The 3 matrices that this method uses as inputs are (1) the measured concentration of marker pigments in the samples; (2) the theoretical ratios of marker pigments to $\mathrm{chl}$ a for each phytoplankton group to be quantified; and (3) a ratio limit matrix restricting the iterative adjustments of these ratios operated by CHEMTAX.

On the basis of the initial estimate of the pigment:chl a ratios for each selected group to be determined (Matrix 2), CHEMTAX optimizes the contribution of each phytoplankton group to the total chl a using a factor analysis and a steepest-descent algorithm and finds the best fit to the measured pigment data. Several initial accessory pigment:chl a ratio matrices were tested here (see below). Beside the partial chl a attributed to each phytoplankton group, one other output is a new matrix of pigment:chl a ratios resulting from the best fit. For each sample, 10 successive CHEMTAX runs were performed by using the output pigment:chl a ratios matrix of each run as input for the following run in order to have those ratios stabilize toward their most probable values (Latasa 2007). The parameters set for the calculations were as given by Latasa (2007).

The different input pigment:chl a ratio matrices tested here include or exclude chl $c_{1}+C_{2}$, Dtx and Caro, which are shared by many phytoplankton groups (Jeffrey \& Vesk 1997). Ddx was not taken out from any of the initial ratio matrices, as it was strongly correlated with the unshared pigment of dinoflagellates, Peri $\left(\mathrm{r}^{2}=\right.$ 0.98, p < 0.05). It should also be noted that Allo:chl a ratios used in the different matrices corresponded to 
free-living cryptophytes, not to the kleptoplastidic ciliate Mesodinium rubrum. The following pigment:chl a ratio matrices were tested: (1) the mean values from Mackey et al. (1996) for 7 accessory pigments (Table 2, Appendix 1, available as MEPS Supplementary Material at www.int-res.com/articles/suppl/m359p069_app. pdf; NB chl a does not include chlide a); (2) the values for chl $C_{1}+C_{2}$, Dtx and Caro from Mackey et al. (1996), as well as the 7 accessory pigments in Table 2; (3) the mean values from Schlüter et al. (2000) for the 7 accessory pigments from Table 2 for species of mainly Scandinavian waters; (4) the same groups as in (3), but including the mean values for chl $C_{1}+C_{2}$, Dtx and Caro taken from Schlüter et al. (2000); and (5) the maximum values for each phytoplankton group from Mackey et al. (1996), Schlüter et al. (2000) and Henriksen et al. (2002) for the same 7 accessory pigments of Table 2, in order to test the capacity of CHEMTAX to deal with extreme input ratios. However, for chrysophytes, But:chl a ratios of Mackey et al. (1996) were used in all input ratio matrices.

Model II (major axis) linear regression was used in order to assess the functional relationship between random variables (pigment and/or carbon concentrations). Note that the presented regression equations should not be used to predict values of $y$ given $x$ (Sokal \& Rohlf 2000).

\section{RESULTS}

\section{CHEMTAX-derived chl a estimations with different pigment input ratios}

The variability of the final chl a allocation to the major groups (Diat and Dino) due to the use of different pigment ratio matrices was reduced by running the program 10 successive times as reported by Latasa (2007) (Table 3). Thus, the usage of distinct input pigment:chl a ratios did not result in significant differences (relative difference from the average was 1 to
Table 2. Input (from Mackey et al. 1996) and output (after 10 runs) ratios of marker pigments to chl a for the selected phytoplankton groups. Abbreviations defined in Table 1

\begin{tabular}{|c|c|c|c|c|c|c|c|c|}
\hline & \multirow[b]{2}{*}{ Peri } & \multirow[b]{2}{*}{ But } & \multirow{2}{*}{$\overline{\text { Fuco }}$} & \multicolumn{2}{|c|}{ Marker pigments } & \multirow{2}{*}{ Zea } & \multirow[b]{2}{*}{ chl $b$} & \multirow[b]{2}{*}{$\operatorname{chl}$} \\
\hline & & & & Allo & $\operatorname{Ddx}$ & & & \\
\hline \multicolumn{9}{|c|}{ Input ratios } \\
\hline Dino & 0.532 & 0 & 0 & 0 & 0.121 & 0 & 0 & 1 \\
\hline Diat & 0 & 0 & 0.46 & 0 & 0.24 & 0 & 0 & 1 \\
\hline Crypto & 0 & 0 & 0 & 0.23 & 0 & 0 & 0 & 1 \\
\hline Chryso & 0 & 0.467 & 0.560 & 0 & 0.28 & 0 & 0 & 1 \\
\hline Eugleno & 0 & 0 & 0 & 0 & 0.23 & 0 & 0.41 & 1 \\
\hline Chloro & 0 & 0 & 0 & 0 & 0 & 0.059 & 0.285 & 1 \\
\hline Cyano & 0 & 0 & 0 & 0 & 0 & 0.11 & 0 & 1 \\
\hline \multicolumn{9}{|c|}{ Output ratios } \\
\hline Dino & 0.424 & 0 & 0 & 0 & 0.181 & 0 & 0 & 1 \\
\hline Diat & 0 & 0 & 0.465 & 0 & 0.059 & 0 & 0 & 1 \\
\hline Crypto & 0 & 0 & 0 & 0.258 & 0 & 0 & 0 & 1 \\
\hline Chryso & 0 & 0.465 & 0.560 & 0 & 0.279 & 0 & 0 & 1 \\
\hline Eugleno & 0 & 0 & 0 & 0 & 7.945 & 0 & 9.838 & 1 \\
\hline Chloro & 0 & 0 & 0 & 0 & 0 & 0.057 & 0.458 & 1 \\
\hline Cyano & 0 & 0 & 0 & 0 & 0 & 0.770 & 0 & 1 \\
\hline
\end{tabular}

Table 3. Chl a contributions of distinct phytoplankton groups to the total chl a calculated by CHEMTAX using different initial ratio matrices. Matrix 5 is the maximal pigment:chl a ratios for each phytoplanktion group reported in Mackey et al. (1996), Schlüter et al. (2000) and Henriksen et al. (2002). Abbreviations defined in Table 1

\begin{tabular}{|c|c|c|c|c|c|c|c|c|c|}
\hline \multirow[t]{2}{*}{ Ratio matrix no. } & \multirow{2}{*}{$\overline{\text { Dino }}$} & \multirow[b]{2}{*}{ Crypto } & \multirow{2}{*}{$\begin{array}{c}\text { Chl } \\
\text { Chryso }\end{array}$} & \multirow{2}{*}{$\begin{array}{c}\text { contributi } \\
\text { Eugleno }\end{array}$} & \multirow{2}{*}{$\begin{array}{l}\text { as }(\%)- \\
\text { Chloro }\end{array}$} & \multirow[b]{2}{*}{ Cyano } & \multirow[b]{2}{*}{ Diat } & \multirow{2}{*}{$\begin{array}{c}\text { No. of } \\
\text { pigments }\end{array}$} & \multirow[t]{2}{*}{ Source } \\
\hline & & & & & & & & & \\
\hline \multicolumn{10}{|l|}{ Output of 1 st run } \\
\hline 1 & 44.34 & 33.57 & 2.06 & 0.27 & 1.52 & 1.01 & 17.23 & 7 & Mackey et al. (1996) \\
\hline 2 & 40.44 & 36.55 & 1.36 & 3.53 & 0.99 & 2.17 & 14.96 & 10 & Mackey et al. (1996) \\
\hline 3 & 31.11 & 35.36 & 1.32 & 1.05 & 1.36 & 15.81 & 14.00 & 7 & Schlüter et al. (2000) \\
\hline 4 & 44.76 & 33.36 & 1.27 & 4.98 & 3.60 & 0.37 & 11.66 & 10 & Schlüter et al. (2000) \\
\hline 5 & 55.11 & 2.19 & 0.41 & 2.23 & 19.91 & 0.25 & 19.91 & 7 & \\
\hline Avg & 43.15 & 28.20 & 1.28 & 2.41 & 5.48 & 3.92 & 15.55 & & \\
\hline $\mathrm{SD}$ & 8.76 & 14.60 & 0.59 & 1.89 & 8.13 & 6.69 & 3.15 & & \\
\hline \multicolumn{10}{|c|}{ Output after 10th run } \\
\hline 1 & 44.40 & 33.00 & 1.30 & 0.10 & 1.90 & 0.70 & 18.60 & 7 & Mackey et al. (1996) \\
\hline 2 & 41.40 & 35.24 & 1.33 & 3.24 & 1.10 & 1.31 & 16.38 & 10 & Mackey et al. (1996) \\
\hline 3 & 39.14 & 33.41 & 1.32 & 1.75 & 0.95 & 6.13 & 17.31 & 7 & Schlüter et al. (2000) \\
\hline 4 & 41.88 & 32.31 & 1.30 & 5.59 & 2.04 & 0.40 & 16.46 & 10 & Schlüter et al. (2000) \\
\hline 5 & 42.52 & 2.14 & 0.41 & 1.61 & 32.67 & 0.26 & 20.39 & 7 & \\
\hline Avg & 41.87 & 27.22 & 1.13 & 2.46 & 7.73 & 1.76 & 17.83 & & \\
\hline $\mathrm{SD}$ & 1.90 & 14.06 & 0.41 & 2.08 & 13.95 & 2.47 & 1.69 & & \\
\hline
\end{tabular}


$15 \%$ ) in chl a allocations to these 2 groups (as seen in the results of the tenth run for Matrices 1 through 5 in Table 3). Even though Crypto is a major phytoplankton group, the Allo:chl a ratio did not converge when a very high ratio $(\sim 10$ to 20 times higher than in other matrices) was used in Matrix 5. Successive runs of CHEMTAX did not bring about the convergence of pigment:chl a ratios; thus there was no convergence of chl a allocations for minor phytoplankton groups (Table 3). The percentage contributions of the minor groups Chryso, Chloro, Eugleno and Cyano to the total chl a differed (relative difference $\sim 20$ to $190 \%$ ) among distinct ratio matrices.

Based on the comparison between phytoplankton C estimations and pigment concentrations, Matrix 1 was chosen as the most appropriate among the tested matrices, though it did not produce a good correlation between group-chl $a$ and group-C for minor phytoplankton groups. Matrices 2 and 4 included the ambiguous pigments chl $C_{1}+C_{2}$, Caro and Dtx, and both produced high contribution by Eugleno to the total chl a (Table 3). However, the $\mathrm{C}$ biomass of euglenophytes (which are easy to identify under microscope) was not so high in the samples compared to Chloro-C or Cyano-C. Considering the low Zea concentrations, the contribution of Cyano to the total chl a appeared to be overestimated upon running Matrix 3 (Table 3). When Matrix 5 was run, Chloro-chl $a$ was found to be higher than Diat-chl $a$ and Crypto-chl $a$, which does not seem possible, given that $\mathrm{C}$ biomass of diatoms and cryptophytes were $\sim 20$ and 70 times higher, respectively, than that of chlorophytes. Furthermore, Fuco and Allo concentrations were $\sim 4$ times higher than chl $b$.

The ratios Fuco:chl $a$ for Diat and Peri:chl $a$ for Dino converged (at $0.452 \pm 0.02$ and $0.489 \pm 0.03$, respectively) at the end of the tenth run in all matrices used, even though initial input ratios were about 2 to 3 times higher for Matrix 5 than for the others (see Appendix 1, Fig. 2). The Allo:chl a ratio converged (at $0.251 \pm 0.01$ ) when Matrices 1 through 4 were used but (as mentioned above) remained constant in Matrix 5. Pigment:chl a ratios of minor groups did not converge. For comparisons of different phytoplankton groups' contributions to total $\mathrm{C}$ and $\mathrm{chl} a$, results from only Matrix 1 are shown.

\section{Hydrography}

Surface temperature and salinity (average values within the first meter) showed a gradient, with values from ap-

proximately $9^{\circ} \mathrm{C}$ and 3.5 psu in the Bight of Gdańsk to between 4 and $5^{\circ} \mathrm{C}$, and 7 and 8 psu in the open Baltic Sea. In the southern Baltic Sea, the maximum fresh water runoff occurs in April-May and coincides with the phytoplankton spring bloom initiated by the stabilization of the water column and increased surface light (Kowalczuk et al. 2005). The Vistula and Oder, flowing into the Gdańsk and the Pomeranian Bights, respectively, are the major rivers draining most of Poland.

\section{Species and size composition of phytoplankton}

Autotrophic dinoflagellate Perdinella catenata Levander had the highest average $\mathrm{C}$ biomass among dinoflagellate species, accounting for $29 \%$ of total C biomass and $58 \%$ of Dino-C in the study region excluding 4 stations in the Pomeranian Bight where this species was not detected (Table 4). This species contributed to the total dinoflagellate $\mathrm{C}$ biomass at a higher rate in the Gotland Sea, accounting for $67 \%$ of total Dino-C. The second most important species in terms of $\mathrm{C}$ was the phototrophic ciliate Mesodinium rubrum Lohmann, which constituted $70 \%$ and $60 \%$ of total phytoplankton $\mathrm{C}$ biomass at the first 2 sampling stations. The diatom Thalassiosira baltica (Grunow) Ostenfeld (Table 4), which was also more abundant in the Gotland Sea ( $60 \%$ of total Diat-C), was the third most important species in terms of C. Except Asterionella formosa Hassall, which was more abundant in the Bornholm Sea, other species noted in Table 4 also had higher $\mathrm{C}$ biomass in the Gotland Sea.

Phytoplankton cells 10 to $100 \mu^{3}$ in $V$ constituted $\sim 80 \%$ of total abundance, while $\sim 70 \%$ and $20 \%$ of total C biomass were formed by cells $10^{3}$ to $10^{4} \mu^{3}$ and $10^{4}$ to $10^{5} \mu \mathrm{m}^{3}$ in $V$, respectively.$$
\text { 塞 }
$$
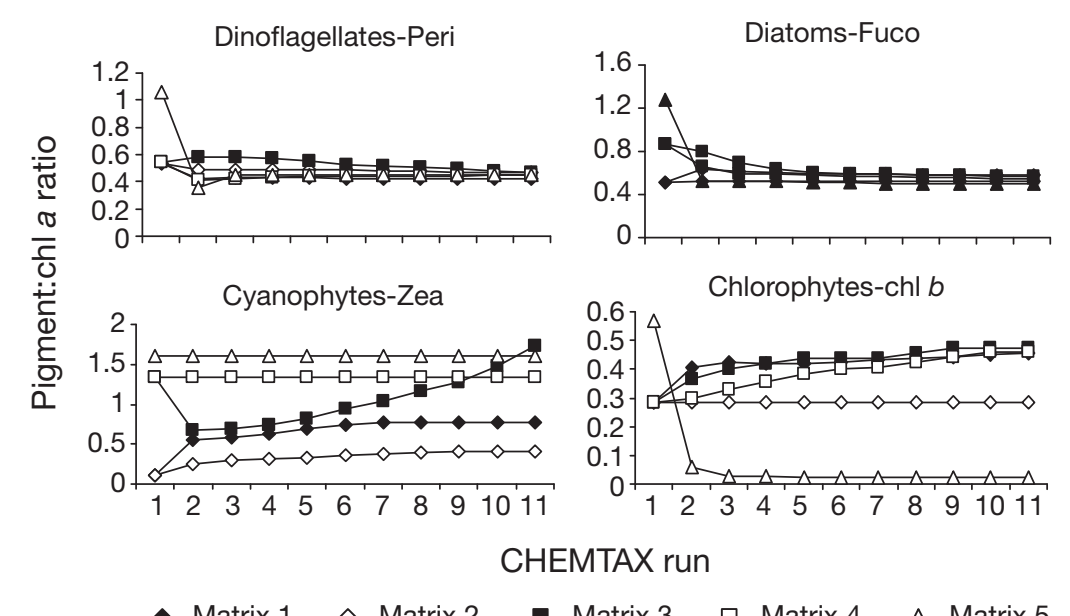

Fig. 2. Variations in pigment ratios after successive runs of CHEMTAX for 4 phytoplankton pigment groups. Abbreviations defined in Table 1 
Table 4. Dominant phytoplankton species, their phototrophic characters (for dinoflagellates) and average carbon concentrations at the sampling stations

\begin{tabular}{|c|c|c|}
\hline $\begin{array}{l}\text { Group } \\
\text { Species }\end{array}$ & Phototrophic character (source) & $\begin{array}{c}\text { Average } \\
\text { carbon }\left(\mu g \mathrm{l}^{-1}\right)\end{array}$ \\
\hline \multicolumn{3}{|l|}{ Dinoflagellate } \\
\hline Peridiniella catenata Levander & Autotrophic, Bralewska \& Witek (1995) & $91 \pm 160$ \\
\hline Achradina pulchra Lohmann & No information & $9 \pm 11$ \\
\hline Gymnodinium spp. & & $2 \pm 10$ \\
\hline $\begin{array}{l}\text { Heterocapsa rotundata (Lohmann) comb. nov. } \\
\text { (= Katodinium rotundatum (Lohmann) Loeblich) }\end{array}$ & Autotrophic, Bralewska \& Witek (1995) & $2 \pm 4$ \\
\hline Gyrodinium spirale (Bergh) Kofoid et Swezy & Heterotrophic, Kim \& Jeong (2004) & $2 \pm 2$ \\
\hline Protoperidinium bipes (Paulsen) Balech & Heterotrophic, Bralewska \& Witek (1995) & $1 \pm 2$ \\
\hline Katodinium glaucum (Lebour) Loeblich III & $\begin{array}{l}\text { Heterotrophic or mixotrophic, } \\
\text { Mouritsen \& Richardson (2003) }\end{array}$ & $1 \pm 1$ \\
\hline \multicolumn{3}{|c|}{$x_{0}$} \\
\hline $\begin{array}{l}\text { Mesodinium rubrum Lohmann } \\
\text { (= Myrionecta rubra Jankowski) }\end{array}$ & Photosynthetic, Gustafson et al. (2000) & $70 \pm 109$ \\
\hline Diatom & Autotrophic, Jeffrey \& Vesk (1997) & \\
\hline Thalassiosira baltica (Grunow) Ostenfeld & & $9 \pm 19$ \\
\hline Skeletonema costatum (Grev.) Cleve & & $2 \pm 4$ \\
\hline Asterionella formosa Hassall & & $1 \pm 3$ \\
\hline Coscinodiscus sp. & & $1 \pm 1$ \\
\hline Cyanophyte & Autotrophic, Jeffrey \& Vesk (1997) & \\
\hline Aphanizomenon flos-aqua (L.) Ralf & & $3 \pm 6$ \\
\hline Cryptophyte & Autotrophic, Janson (2004) & \\
\hline Teleaulax amphioxeia (Conrad) Hill & & $2 \pm 2$ \\
\hline
\end{tabular}

\section{Spatial distribution of Phyto-C and chl a}

The $\mathrm{C}$ biomass of total phytoplankton (Phyto-C) and chl a (Fig. 3) were concordant with the salinity gradient. The highest Phyto-C and chl a were observed in the least saline region of the Bight of Gdańsk (more than

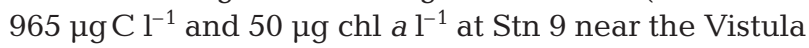
river mouth) and low values were reported in the more saline open sea (less than $10 \mu \mathrm{g} \mathrm{Cl}^{-1}$ and $1 \mu \mathrm{g} \mathrm{chl} \mathrm{a} \mathrm{l}^{-1}$ ). In average, concentrations were higher in the Gotland

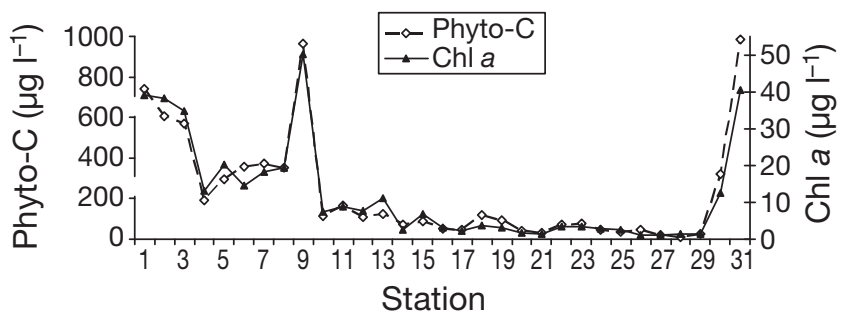

Fig. 3. Variations in phytoplankton C biomass (Phyto-C) and chl a concentrations among the stations
Sea than in the Bornholm Sea (Table 5), even when only offshore areas were considered. Over the whole data set, the average value of chl a was $12.19 \pm 13.98 \mu \mathrm{g}$ $\mathrm{l}^{-1}$ and the chlide a concentration was only $3.1( \pm 1.5) \%$ of the total chl a (chl $a+$ chlide $a)$ concentration.

\section{Relationships among group-specific chl $a$, marker pigments and Phyto-C}

When the average of values from all stations was taken, the composition derived from the CHEMTAX analysis was in reasonable agreement with that derived from microscopic observations for dominant phytoplankton groups (dinoflagellates, cryptophytes and diatoms represented 50,32 and $8 \%$ of the total $\mathrm{C}$ and 44,33 and $19 \%$ of the chl $a$, respectively) (Fig. $4 \mathrm{a}, \mathrm{b})$. For the minor phytoplankton groups, the comparison between chl $a$ and $C$ biomass distributions was much more difficult due to the presence of unidentified small flagellates, which may represent several minor

Table 5. Mean \pm SD phytoplankton biomass (wet wt), carbon biomass and chl $a$ in 2 different regions (all units are $\mu g l^{-1}$ )

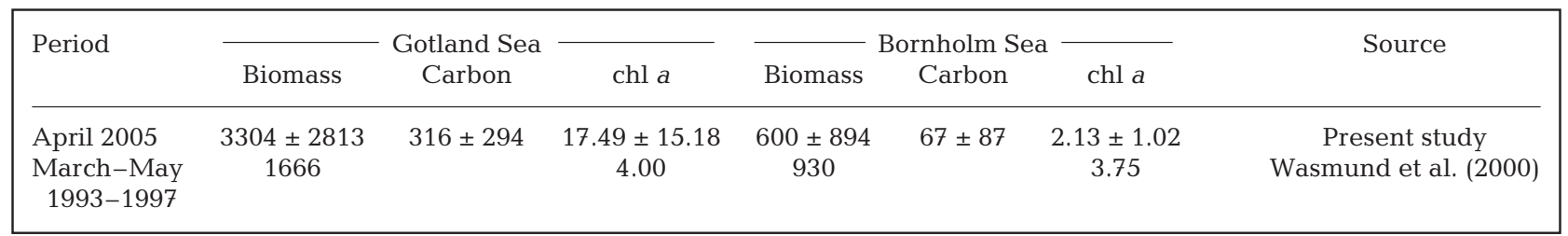




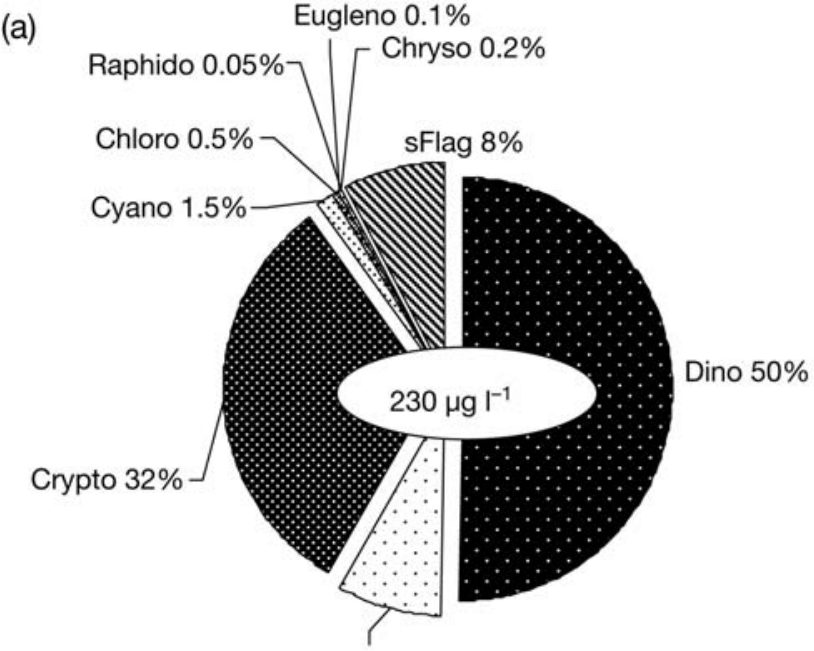

Diat $8 \%$

(c)

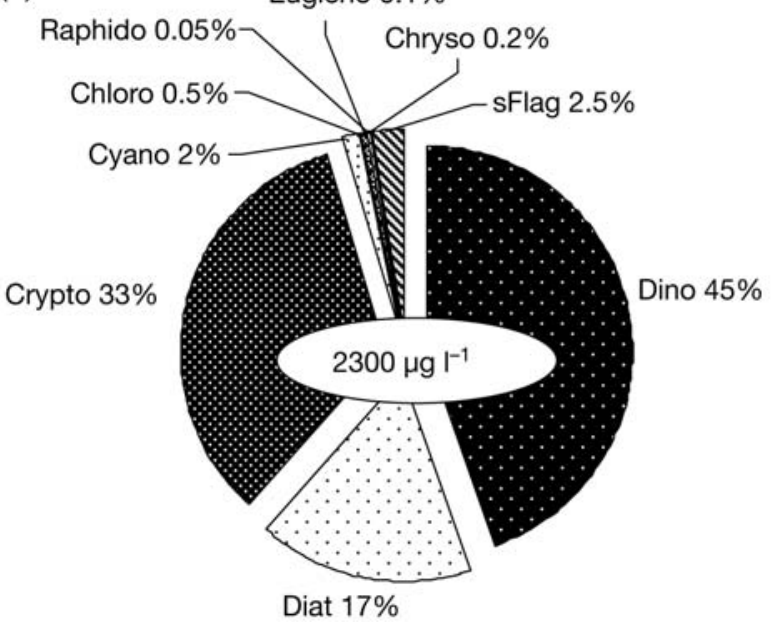

(b)

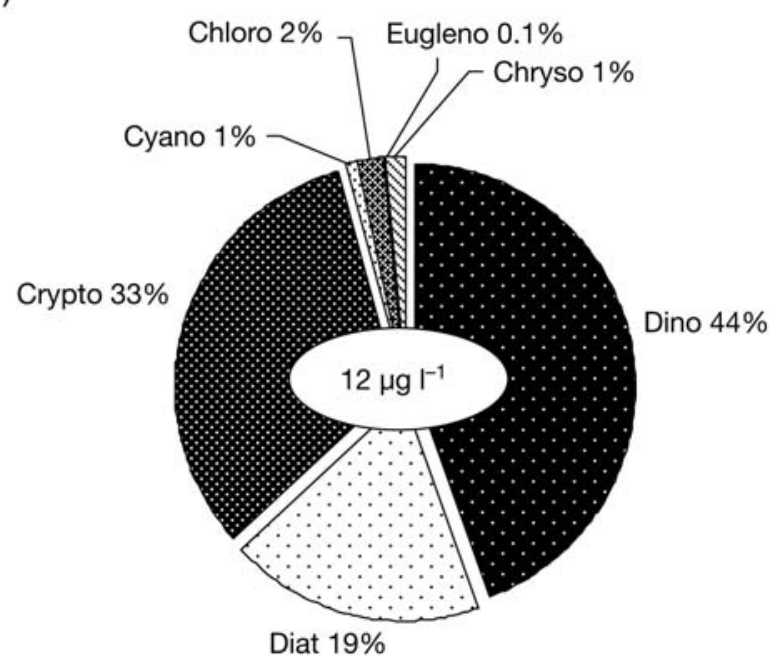

(d)

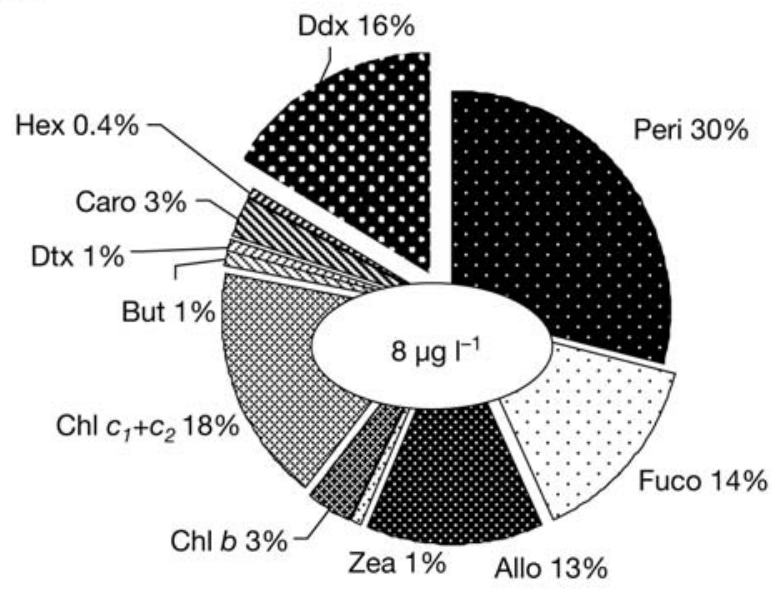

Fig. 4. Phytoplankton classification based on percentages of total (a) carbon biomass (b) chl a obtained from CHEMTAX analysis, (c) biomass (wet wt) and (d) accessory pigments. Numbers at the center of the pie graphs correspond to average absolute values of each variable at all stations. Abbreviations defined in Table 1

groups. The cumulative contribution of minor groups (Chloro, Chryso, Cyano, Eugleno) to the total $\mathrm{C}$ and chl $a$ amounted to $\sim 2.3 \%$ and $4 \%$, respectively (Fig. $4 a, b$ ). Group composition of phytoplankton according to wet wt was mainly different for diatoms and small flagellates (Fig. 4c).

The average concentration of Peri, the unambiguous marker pigment of dinoflagellates, was $2.3 \pm 3.6 \mathrm{\mu g} \mathrm{l}^{-1}$, with values ranging from 0.03 to $14.5 \mathrm{\mu g} \mathrm{l}^{-1}$. Peri represented $30 \%$ of the sum of the measured accessory pigments. Other main contributors were $\mathrm{chl} C_{1}+C_{2}(1.4 \pm$ \left.$1.9{\mu \mathrm{gl}^{-1}}^{-1}\right)$, Ddx $\left(1.3 \pm 1.9 \mathrm{\mu g} \mathrm{l}^{-1}\right)$, Fuco $\left(1.2 \pm 1.3 \mu \mathrm{g} \mathrm{l}^{-1}\right)$, Allo $\left(1.0 \pm 1.4{\mu \mathrm{gl}^{-1}}^{-1}\right.$ (Fig. 4d). The sum of the contributions by other minor pigments represented less than $9.5 \%$.
Peri concentration was significantly correlated with Ddx and chl $C_{1}+C_{2}\left(\mathrm{r}^{2}=0.98\right.$ and 0.92, respectively, $\mathrm{p}<$ 0.05 , Fig. $5 \mathrm{a}, \mathrm{b}$ ), the latter 2 showing almost equal concentrations (slope of the regression equal to 0.99, Fig. 5c) at all sampling stations except Stns 1 and 2, located in the Gdańsk Bight. Ddx and chl $C_{1}+C_{2}$ concentrations were also statistically correlated with Fuco $\left(\mathrm{r}^{2}=0.56\right.$, and $\mathrm{r}^{2}=0.60$, respectively, $\mathrm{p}<0.05$, Fig. $5 \mathrm{~d}, \mathrm{e})$, although the correlations were weaker than with Peri. Concentrations of the less dominant pigments, chl $b$ and Zea, covaried among the stations $\left(\mathrm{r}^{2}=\right.$ 0.89 , p $<0.05$, Fig. 5f).

The variations of phytoplankton composition resulting from microscopy-derived carbon biomass, from 

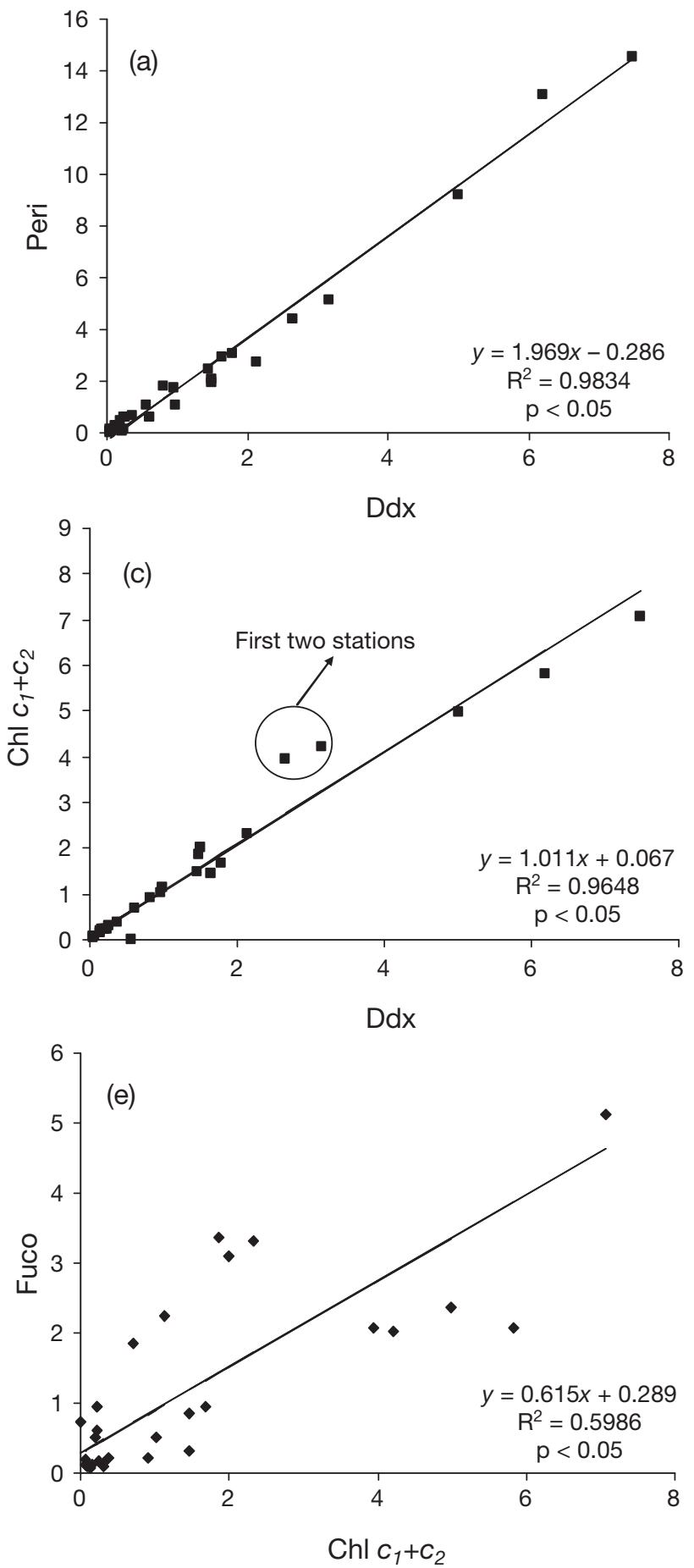
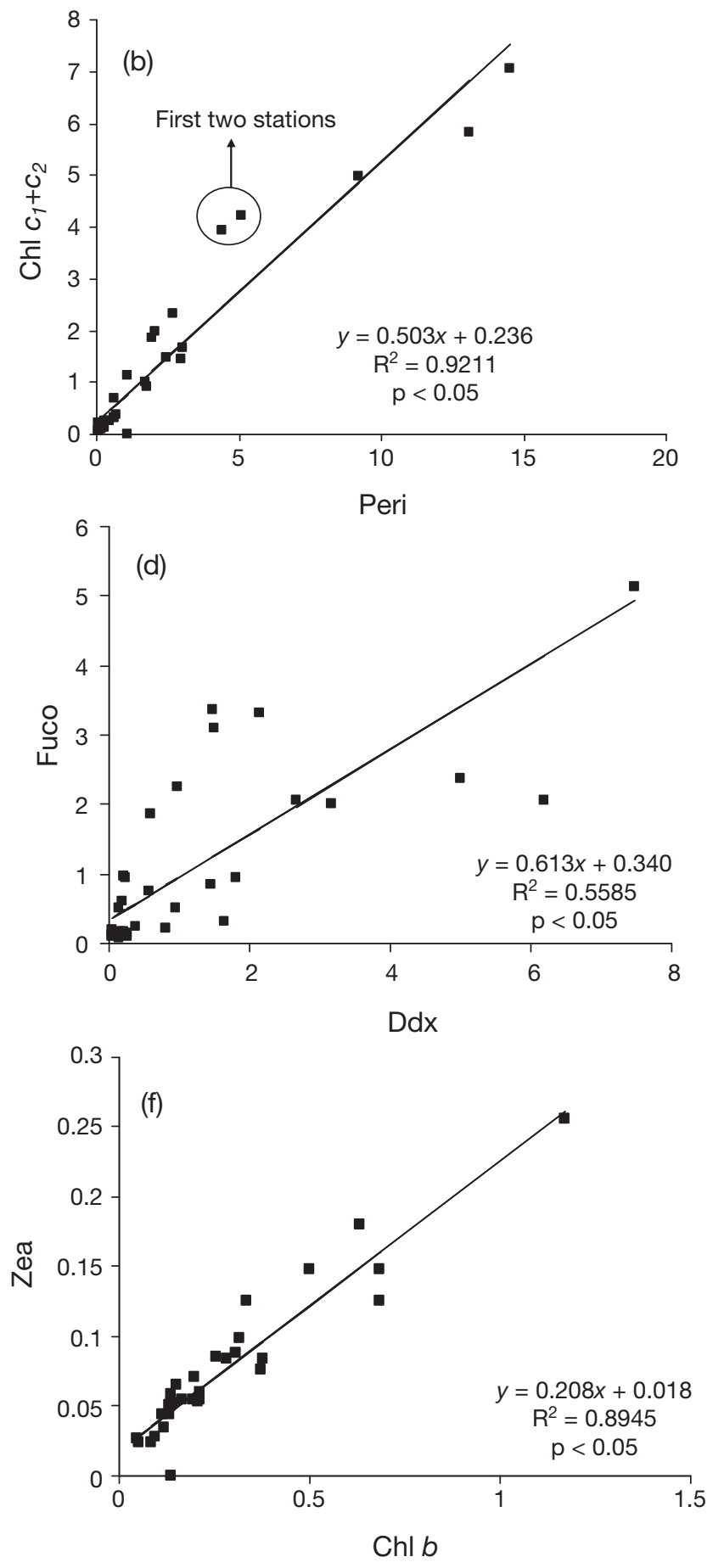

Fig. 5. Model II linear regressions (and corresponding parameters) computed for selected pairs of accessory pigments (units are $\mu \mathrm{g} \mathrm{l}^{-1}$ ). Abbreviations defined in Table 1

CHEMTAX and from the individual marker pigment composition were similar among the stations (Fig. 6). The highest $\mathrm{C}$ biomass, total accessory pigment and chl a concentrations were noted at the Bight of Gdańsk (Stns 1 through 11 and 31), where dino- flagellates and cryptophytes were dominant. These groups were still dominant at the central Polish coasts (Stns 20, 21 and 29). However, in the Pomeranian Bight (Stns 22 through 25) the contribution of dinoflagellates, and thus of Peri, to the total carbon biomass and total 


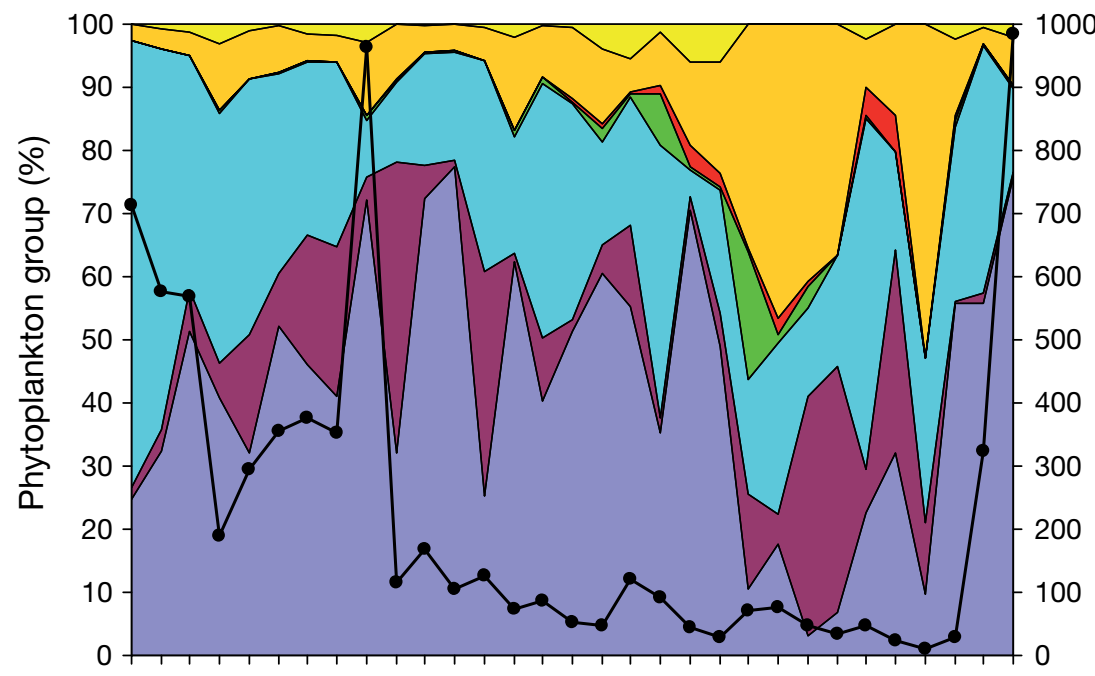

(a)

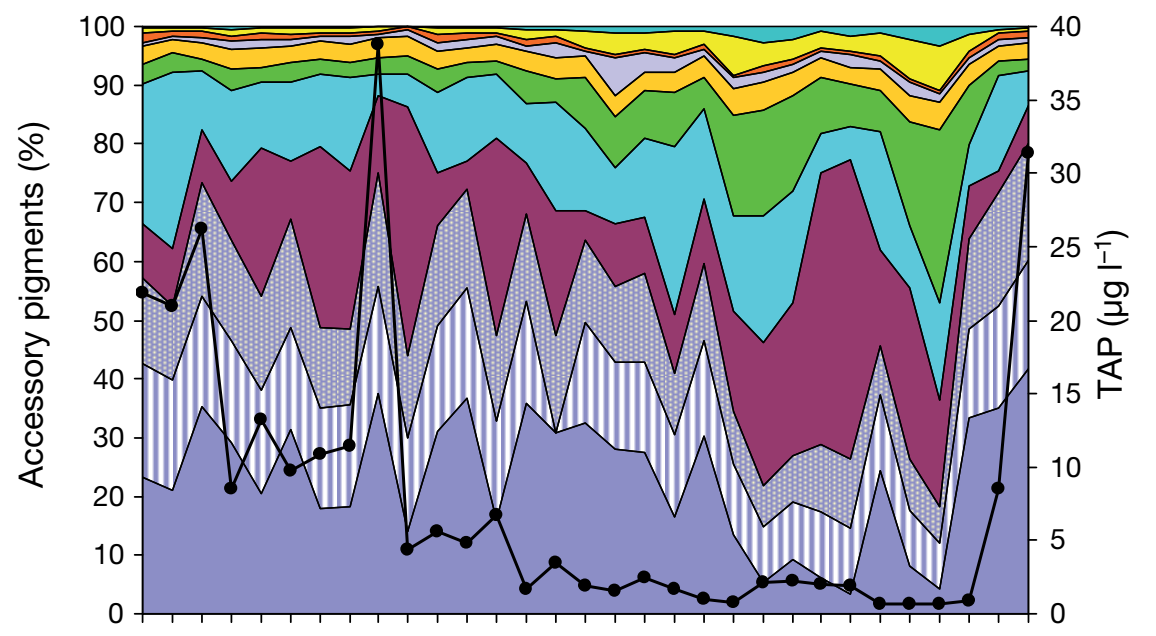

$\square$ Cyano-C

$\square$ sFlag. $-\mathrm{C}$

$\square$ Chryso-C

$\square$ Chloro+Eugleno-C

$\square$ Crypto-C

$\square$ Diat-C

$\square$ Dino-C

- Total carbon

(b)

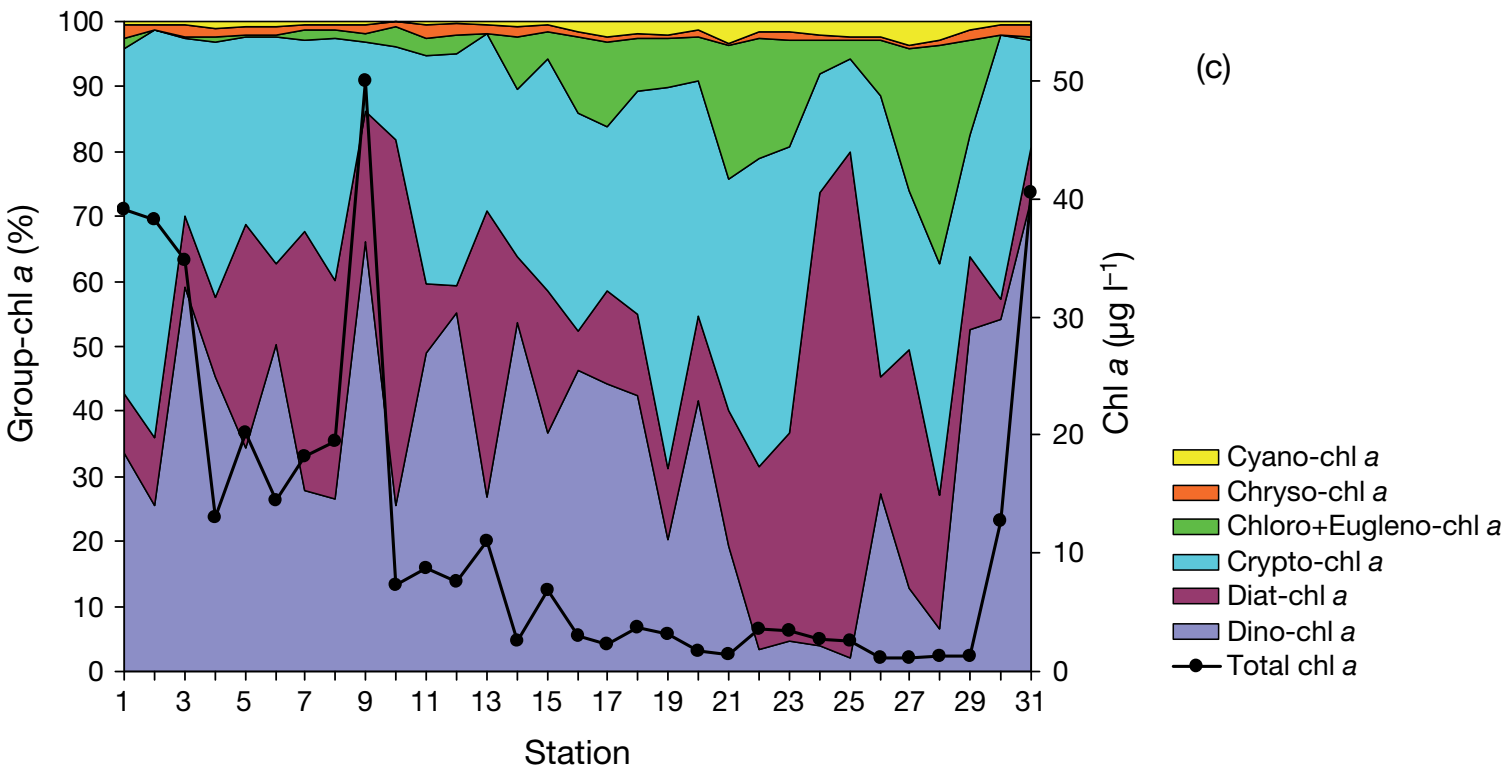

Fig. 6. Percentage contribution of (a) phytoplankton groups to the total carbon, (b) pigments to the total accessory pigments (TAP) and (c) CHEMTAX-allocated chl a of phytoplankton groups to the total chl $a$. Note that cryptophytes also contain the ciliate Mesodinium rubrum. Abbreviations defined in Table 1 

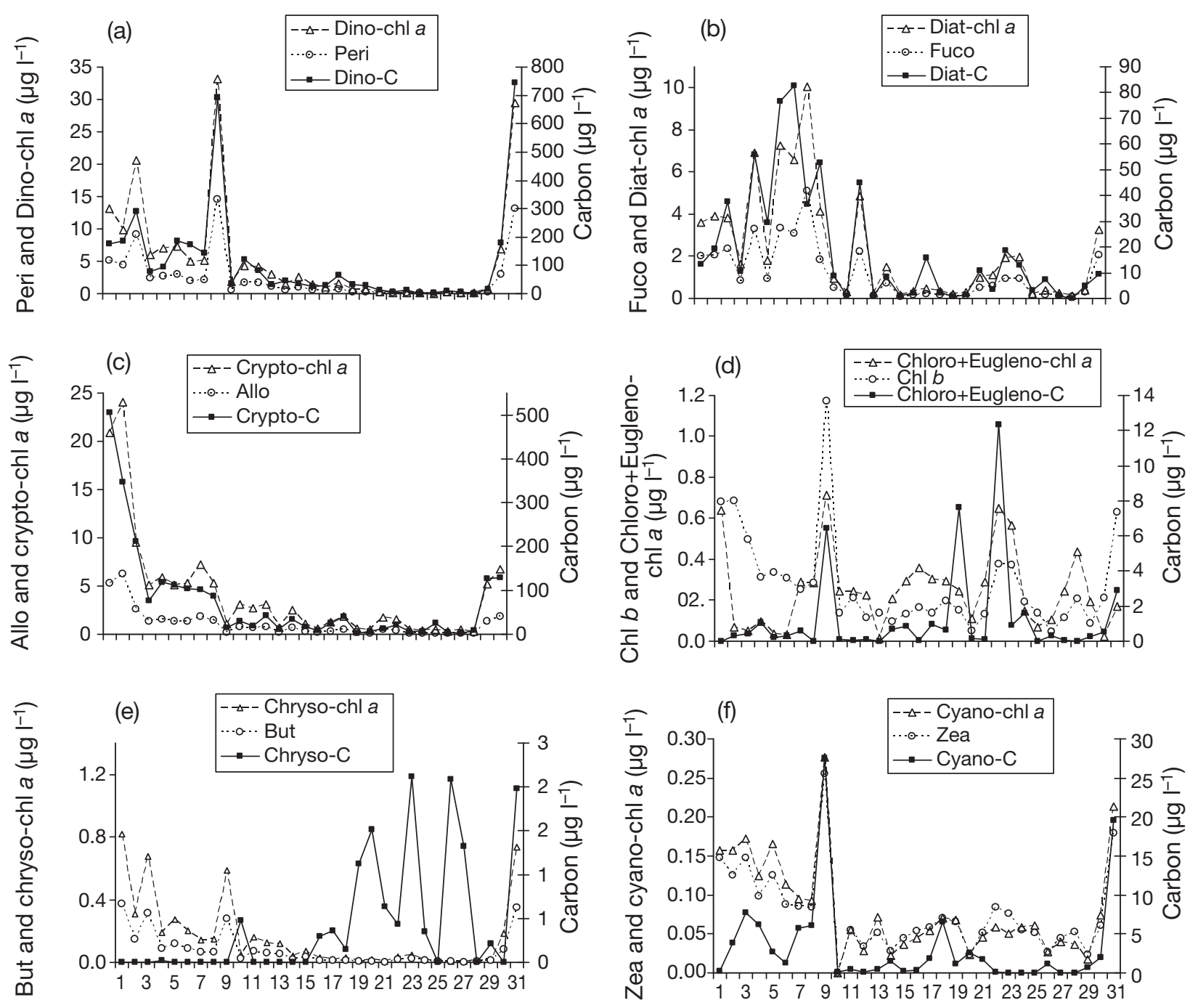

Station

Fig. 7. Distribution of CHEMTAX-allocated chl a of phytoplankton groups together with the corresponding marker pigment and carbon concentrations (all units are $\mu \mathrm{g}^{-1}$ ). Abbreviations defined in Table 1

accessory pigment concentration, respectively, were considerably reduced, while diatom, small flagellates and chlorophyte contributions increased simultaneously with Fuco and chl $b$ contributions (Fig. 6).

In terms of spatial distribution (Fig. $7 \mathrm{a}-\mathrm{C}$ ), $\mathrm{C}$ and chl a concentrations covaried with each other for major phytoplankton groups (dinoflagellates, diatoms and cryptophytes). A significant correlation was found between Dino-C and Peri (Dino-C $=50.49$ Peri -2.22 , $\left.\mathrm{r}^{2}=0.94, \mathrm{p}<0.05\right)$, as well as between Dino-C and CHEMTAX-allocated Dino-chl a $\left(\mathrm{r}^{2}=0.93, \mathrm{p}<0.05\right)$. Similarly, Diat-C was significantly correlated with Fuco (Diat-C $=22.33$ Fuco $-7.16, \mathrm{r}^{2}=0.63, \mathrm{p}<0.05$ ) and Diat-chl a $\left(\mathrm{r}^{2}=0.70, \mathrm{p}<0.05\right)$. However, at some stations (e.g. Stns 1, 2, 9 and 31), CHEMTAX appeared to have overestimated Diat-chl a (Fig. 7b).
The correlation between Dino-C and Ddx $\left(\mathrm{r}^{2}=0.90\right.$, $p<0.05)$ was much higher than between Diat-C and $\operatorname{Ddx}\left(\mathrm{r}^{2}=0.10, \mathrm{p}<0.05\right)$ (not shown). This was in accordance with the decrease in Ddx:chl a ratio for diatoms and its increase for dinoflagellates between the first input and the final output ratios of Matrix 1 (Table 2, not shown in the graph). These observations suggested that Ddx is a good marker pigment of dinoflagellates rather than of diatoms in the present investigation. Similarly, chl $C_{1}+C_{2}$ was much more correlated with Dino-C $\left(\mathrm{r}^{2}=0.82, \mathrm{p}<0.05\right)$ than with Diat-C $\left(\mathrm{r}^{2}=0.13\right.$, $\mathrm{p}<0.05)$ and sFlag-C $\left(\mathrm{r}^{2}=0.50, \mathrm{p}<0.05\right)$.

$\mathrm{C}$ biomass of minor phytoplankton groups was either unrelated or poorly related with their marker pigments or with chl a allocated by CHEMTAX (Fig. 7d-f). CHEMTAX-allocated chl $a$ of Chloro was poorly corre- 
lated with $\mathrm{C}$ biomass of this group $\left(\mathrm{r}^{2}=0.2, \mathrm{p}<0.05\right)$ while there was no correlation between Eugleno-C and Eugleno-chl a ( $p>0.05)$ (Fig. 7d). Since chrysophytes did not include But-containing pelagophytes, no correlation was observed between Chryso-C and Chryso-chl a (Fig. 7e). Cyano-C showed a rather good correlation with Zea $\left(\mathrm{r}^{2}=0.66, \mathrm{p}<0.05\right)$ and Cyanochl a $\left(\mathrm{r}^{2}=0.64, \mathrm{p}<0.05\right)$, mainly due to a good fit at Stns 9 and 31 (Fig. 7f). While the correlation between marker pigments Zea and chl $b$ was significant $\left(\mathrm{r}^{2}=\right.$ 0.89, $\mathrm{p}<0.05$ ), the correlation between Cyano-C (which contain Zea) and Chloro+Eugleno-C (which contain chl $b$ and small amounts of Zea) was not significant $\left(\mathrm{r}^{2}=0.06, \mathrm{p}>0.18\right)$.

Crypto-C (including the phototrophic ciliate Mesodinium rubrum) and Allo were significantly correlated (Crypto-C $=80.29$ Allo $\left.-10.98, \mathrm{r}^{2}=0.91, \mathrm{p}<0.05\right)$. Carbon biomass of $M$. rubrum was well above that of freeliving cryptophytes present in the environment. These ciliates contained $89 \pm 17 \%$ of Crypto-C $(95 \pm 9 \%$ of the cryptophyte wet wt) at the first 2 stations (Fig. 8). High biomass of alloxanthin-containing organisms at these stations could also be deduced from pigment ratios. As previously noted, the $\operatorname{chl} c_{1}+C_{2}$ : Ddx ratio was much higher at Stns 1 and 2 than at all other stations (Fig. 5c). Given that Peri and Ddx were closely associated with Dino-C, and also with chl $C_{1}+C_{2}$, the excess of chl $C_{1}+C_{2}$ (chl $C_{2}$ is also a marker pigment of Crypto) at these stations could be attributed to cryptophytes found as endosymbionts in the environment.

\section{C:chl a ratio and irradiance}

Phyto-C was significantly correlated with chl a $\left(\mathrm{r}^{2}=\right.$ 0.95, $\mathrm{n}=31, \mathrm{p}<0.05$, Fig. 9a) and the average C:chl $a$ ratio was equal to $20 \pm 7$. The average $\mathrm{C}$ :chl a ratio was lower for diatoms $(9 \pm 7)$ than for dinoflagellates $(30 \pm$
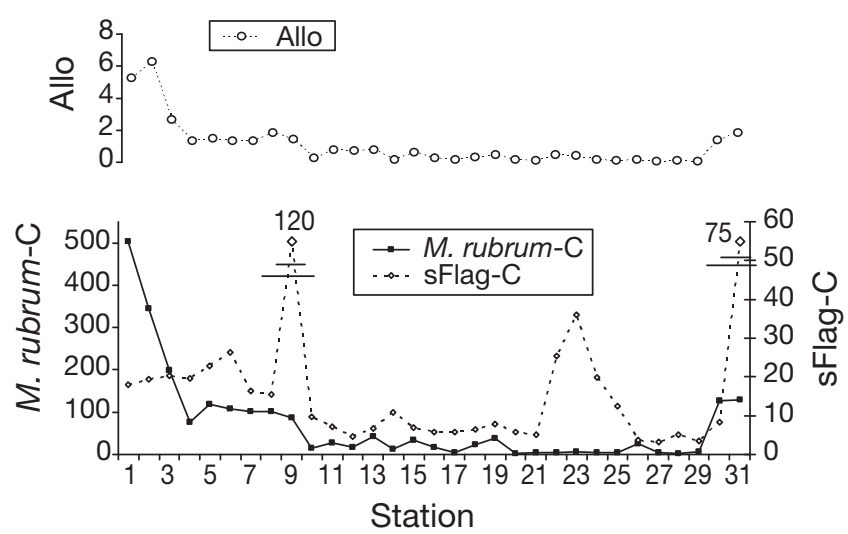

Fig. 8. Alloxanthin (Allo) concentrations and the distribution of the carbon biomass of small flagellates (sFlag) and Mesodinium rubrum (all units are $\mu \mathrm{g}^{-1}$ )
17) and for cryptophytes $(17 \pm 9)$ (Fig. 9b-d). The use of different equations (see 'Materials and methods') resulted in a doubling of the ratio of both diatoms and cryptophytes. When these 2 parallel increases were taken into account, the $\mathrm{C}$ :chl a ratio of total phytoplankton became $28 \pm 10$. The average $\mathrm{C}$ : $\mathrm{chl}$ a ratio considerably differs from the estimated slope of the regression for Cyanophytes as well as for the other groups (Chloro, Eugleno, Chryso and sFlag) (Fig. 9e,f). In fact, the significant linear relationship observed for each of these 2 groups is mainly driven by a couple of anomalous high values.

There was no significant correlation between C:chl a ratio and the average irradiance in the surface mixed layer either for all data (Fig. 10) or for clear sky samples $\left(y=0.609 \ln (x)+19.176, r^{2}=0.003, p>0.83\right)$. These ratios were lower than the optimal C:chl a ratios found using the model of Blackford et al. (2004). When C:chl a ratios of major phytoplankton groups, dinoflagellates, diatoms and cryptophytes, were separately regressed with $I_{\mathrm{SML}}$, correlations were not significant either $\left(\mathrm{r}^{2}=0.034, \mathrm{p}=0.319 ; \mathrm{r}^{2}=0.001, \mathrm{p}=0.967 ; \mathrm{r}^{2}=\right.$ $0.001, \mathrm{p}=0.886$, respectively).

\section{DISCUSSION}

\section{Comparison of CHEMTAX results with different input ratio matrices}

Latasa (2007) reported that the successive runs of CHEMTAX made the pigment ratios converge to the actual pigment:chl a ratios for most phytoplankton groups, greatly improving biomass estimates. In agreement with this statement, in the present study, Fuco:chl $a$ for diatoms and Peri:chl a for dinoflagellates converged at the end of 10 successive runs, with a result of almost the same chl a allocations to these groups (Fig. 2). Similarly, the Allo:chl a ratio of cryptophytes, varying by a factor of 1.5 from Matrix 1 to Matrix 4 (Appendix 1A), converged after the first run. However, it remained unvaried, even after 10 successive runs, for the very high initial ratios of Matrix 5 (11to 17 -fold higher than in Matrices 1 through 4). Latasa (2007) also noted that if a minor group has only a single and unshared marker pigment, chl a concentrations could be correctly quantified, but if it shares marker pigments with major groups, CHEMTAX might not produce reliable results. A strict comparison of our results with Latasa's (2007) findings was not possible since all minor groups shared pigments with either another minor group (e.g. cyanophytes shared Zea with the other minor group chlorophytes) or with a major group (chrysophytes shared Ddx with the major groups, diatoms and dinoflagellates) in this work. 

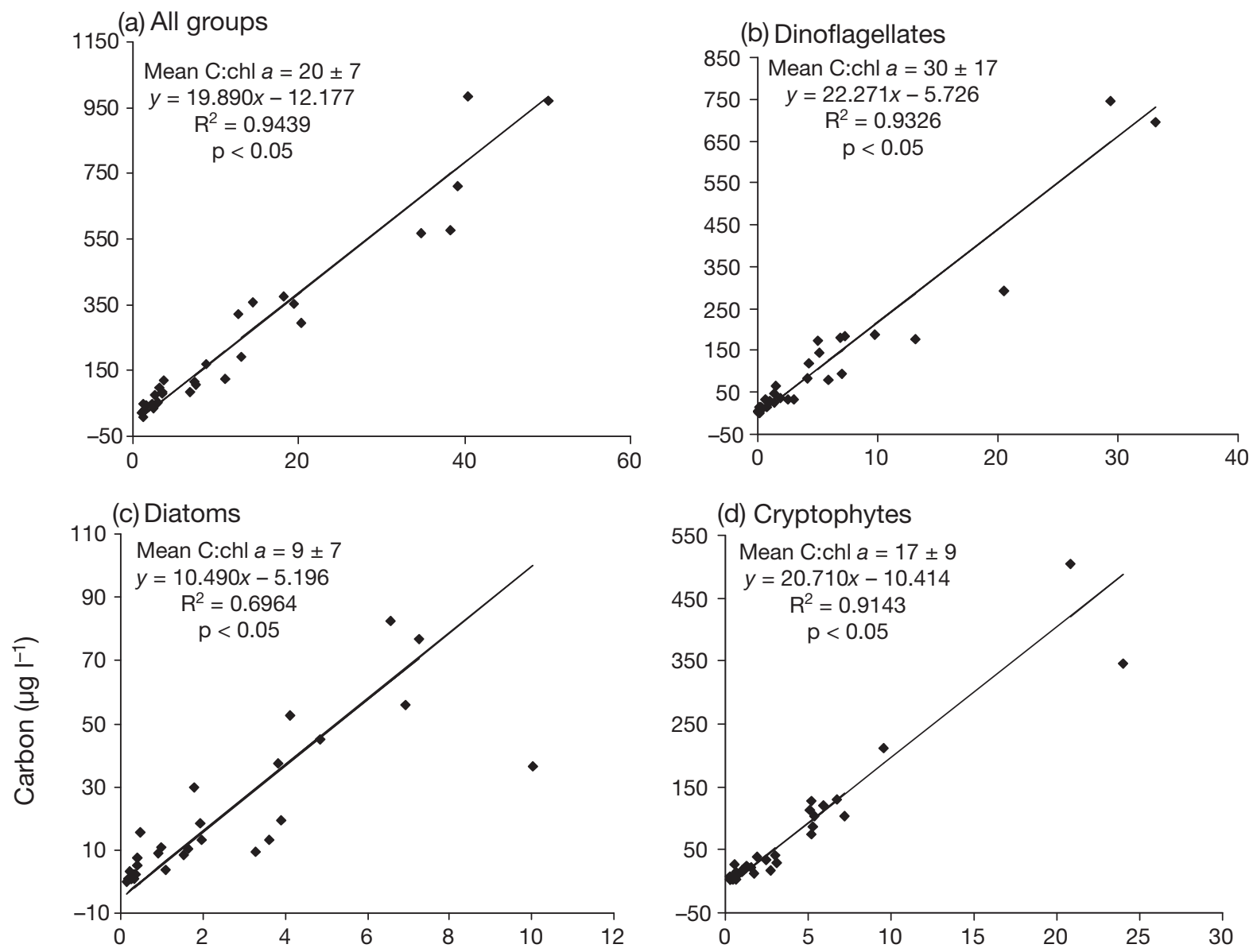

(d) Cryptophytes

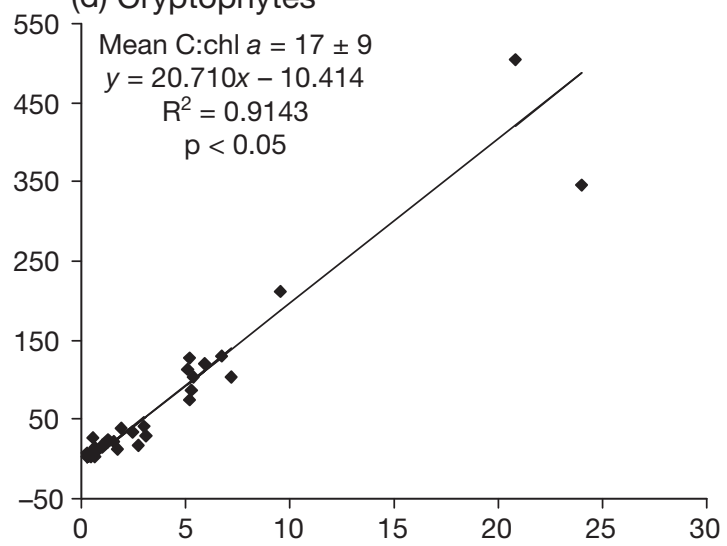

(e) Cyanophytes
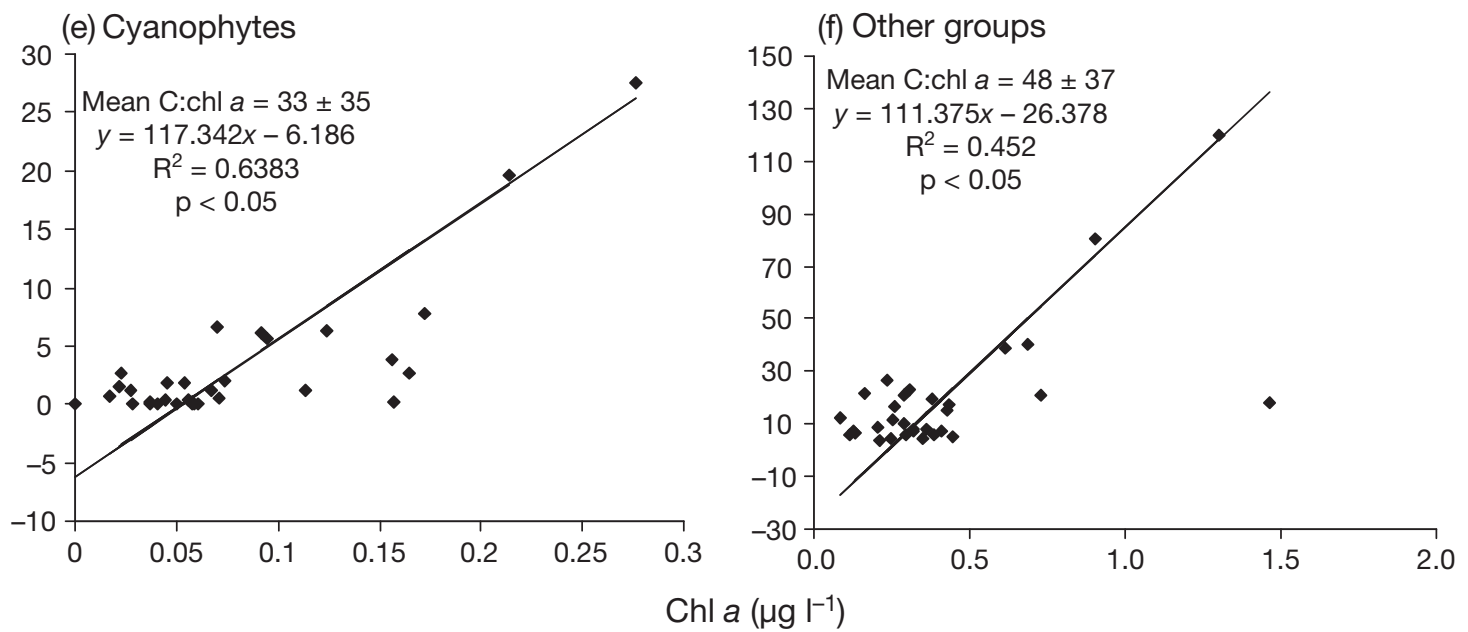

Fig. 9. Model II linear regressions of carbon versus chl a for (a) total phytoplankton, (b) dinoflagellates, (c) diatoms, (d) cryptophytes (including Mesodinium rubrum), (e) cyanophytes and (f) other groups (Chloro, Chryso, Eugleno, sFlag; see Table 1)

None of the pigment:chl a ratios of minor groups converged at the end of 10 successive runs in the present study, partially supporting the finding of Latasa (2007) about the minor groups.

Mackey et al. (1996, p. 268) reported that, 'care should also be taken when selecting what pigments to use in the ratio matrix. Pigments that are present in nearly all phytoplankton are unlikely to give much useful information, while the use of pigments such as diadinoxanthin, which is converted rapidly to diatoxanthin in the light (Demers et al. 1991), or pigments which have wildly different abundances in different 


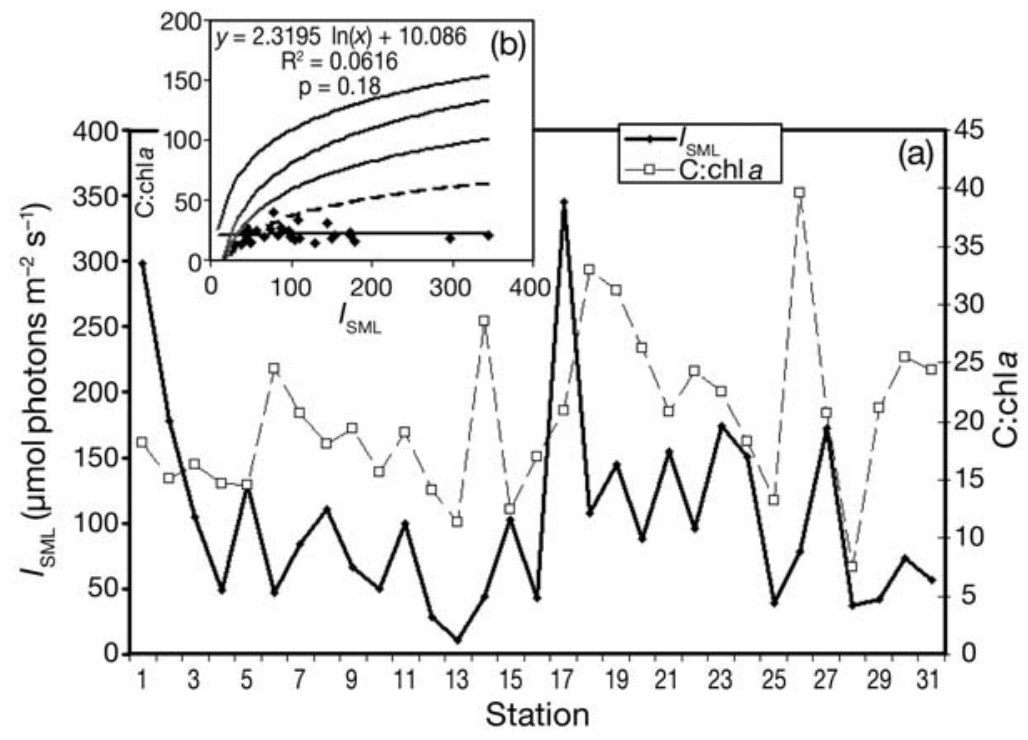

Fig. 10. (a) Variations in irradiance in the surface mixed layer $\left(I_{\mathrm{SML}}\right)$ and C:chl a ratios at the sampling stations. (b) Observed and model-derived C:chl a ratios under different irradiances. The black line and symbols $(\downarrow)$ represent the ratios observed in the present study. Grey lines show optimal C:chl a ratios derived from models of Blackford et al. (2004) and Geider et al. (1997). Each grey line, top to bottom, refers to a maximum assimilation rate of 1,2 and $3 \mathrm{~d}^{-1}$ respectively. Ratios were constrained by maximum 150 and minimum 13. Dashed line was derived using the regression equation of Llewellyn et al. (2005) $(y=$ $-0.0217 \ln (x)+0.1353, \mathrm{r}^{2}=0.91, \mathrm{p}<0.0001$ for 2001). The unit ' $\mu \mathrm{mol}$ photons $\mathrm{m}^{-2}$ $\mathrm{s}^{-1 \prime}$ was converted to ' $\mathrm{W} \mathrm{m} \mathrm{m}^{-2}$ ' assuming $1 \mathrm{~W} \mathrm{~m}^{-2}=1.89 \mu \mathrm{mol}$ photons $\mathrm{m}^{-2} \mathrm{~s}^{-1}$ as in Llewellyn et al. (2005)

species within a class are also likely to give poor results.' When the widely shared $\mathrm{chl} \mathrm{C}_{1}+C_{2}$, Caro and Dtx were included in the ratio matrices, concentrations of major groups were not affected but some minor groups were influenced. Euglenophytes were overestimated when these 3 pigments were used. Ddx was not excluded from any of the tested input ratio matrices even though it is a shared pigment by many phytoplankton groups, since in the present study, Ddx was very well correlated with Peri and Dino-C.

\section{Phyto-C, Phyto-chl a and marker pigment relationship}

The dominance of dinoflagellates during the study period at almost all stations was evidenced by all 3 methods used here to determine the phytoplankton composition: (1) the use of the sole marker pigments (Peri, Ddx, chl $C_{1}+C_{2}$ ), (2) the CHEMTAX analysis and (3) the microscopic examination (Fig. 4).

In many previous investigations performed in different seas, the chl a allocation to the dinoflagellates by CHEMTAX was not well correlated with the microscopic carbon evaluation of this class (Irigoien et al. 2004, Llewellyn et al. 2005, Rodriguez et al. 2006).
This could be due to the presence of heterotrophic/mixotrophic dinoflagellates as well as of unusual pigment contents (in Fuco, Allo, Hex, chl $b$ ) of some dinoflagellates (Sournia et al. 1992, Johnsen \& Sakshaug 1993, Jeffrey \& Vesk 1997, Meyer-Harms \& Pollehne 1998). By contrast, in the present investigation, significant positive correlations between Dino-C and Dino-chl a-as well as between Dino-C and the marker pigments Peri, Ddx and chl $C_{1}+C_{2}-$ were noteworthy (except chl $C_{1}+C_{2}$ at Stns 1 and 2). This must be due to the dominance of Peri-containing autotrophic dinoflagellates (Table 4). Good correlations between Dino-C and Peri, and also between Dino-C and Ddx, were reported previously in the Baltic Sea, in the Gulf of Bothnia and the Gulf of Finland (Piippola \& Kononen 1995, Wänstrand \& Snoeijs 2006).

According to CHEMTAX and microscopy results, the second important phytoplankton group contributing to the total chl $a$ and $C$ biomass was cryptophytes when the kleptoplastidic ciliate Mesodinium rubrum was included in that group (Figs. 4a-c, 6a,c). This ciliate was a significant source of Phyto-C and chl $a$ in the Bight of Gdańsk, especially at Stns 1 and 2 (Fig. 8). M. rubrum was also previously reported to be an important phototrophic ciliate in the Gdańsk Basin (Witek 1998, Rychert 2004) and was noted to reach bloom concentrations (up to $\sim 200 \mu \mathrm{g} \mathrm{C}^{-1}$ ) generally in April-July and October in the southern Baltic proper and Danish estuaries (Witek 1998, Henriksen et al. 2002, Schlüter \& Møhlenberg 2003, Wasmund et al. 2005). Although not mentioned, M. rubrum could also be the explanation for the observed high Allo concentration while cryptophyte biomass was low in the northern Baltic Sea (Wänstrand \& Snoeijs 2006). Crypto-C was significantly correlated with Allo $\left(\mathrm{r}^{2}=\right.$ 0.91) and with Crypto-chl a $\left(r^{2}=0.91\right)$.

Diat-C values were also well correlated with Fuco and CHEMTAX-allocated chl a concentrations $\left(\mathrm{r}^{2}=\right.$ 0.63 and $\left.r^{2}=0.70, p<0.05\right)$. However, at a few stations (e.g. Stns 9 and 31), diatoms seemed to be overestimated by CHEMTAX, probably due to the dominance of Fuco-containing small flagellates (e.g. chrysophytes) at these stations (Figs. 7b \& 8). It was previously reported that large-sized diatoms had lower cellular chl a content with respect to smallsized individuals and thus were omitted in the comparison studies of biomass and pigment analyses 
(Schlüter \& Møhlenberg 2003 and references therein). In the present study, the discrepancy between Diat-C and Diat-chl $a$ at the few stations mentioned above cannot be due to differences in cellular pigment content originating from distinct size composition of diatoms, because small-sized diatom species such as Thalassiosira baltica (Grunow) Ostenfeld and/or Skeletonema costatum (Grev.) Cleve were dominant among the stations (Table 4).

The spatial distribution of phytoplankton groups containing chl $b$ (chlorophytes and euglenophytes) or Zea (cyanophytes) generally differed according to the estimator of their abundance-the respective individual marker pigments chl $b$ or Zea, CHEMTAXallocated chl $a$, or C estimated from biovolume (Figs. 6 $\& 7 d, f)$. Nonetheless, the contribution of these groups to the total accessory pigment and total carbon was low (Fig. 4a,d).

\section{Spatial distribution of Phyto-C and marker pigments}

It is helpful to know dominant phytoplankton groups, species and their bloom dynamics in a study region when estimating $\mathrm{C}$ biomass from pigment composition or from light absorption characteristics. In the present study, the dominant phytoplankton species were typical bloom-forming species of the region (Table 4). A spring dinoflagellate bloom, dominated by Peridiniella catenata, is common for the southern Baltic Sea according to long-term monitoring studies of the region (HELCOM 1996, Wasmund et al. 1998, Stoń et al. 2002, Gasiunaite et al. 2005). P. catenata-dominated blooms were also observed in the northern parts of the Baltic Sea, the Gulf of Finland and the Gulf of Riga in spring (Gasiunaite et al. 2005). According to these investigations (op. cit.), the biomass level of the bloom is generally higher in the southeastern Baltic Sea than in the southwestern part. Similarly, phytoplankton biomass and chl a concentration were several-fold higher in the eastern Baltic than in the western Baltic in the present investigation (Table 5). Such a difference in Phyto- $\mathrm{C}$ and chl a concentrations between the 2 areas could partially be due to the time lag between bloom occurrences as well. It was previously reported that the spring bloom initiates and ends earlier in the western part of the southern Baltic Sea than in the east (Wasmund et al. 1998, Gasiunaite et al. 2005). Moreover, it was noted that the bloom was mainly composed of diatoms in the southwestern Baltic and of dinoflagellates in the southeast (Wasmund et al. 1998, Gasiunaite et al. 2005). In the present study as well, diatoms and small flagellates were dominant at the 4 western-most stations (Stns 22 to 25), where the total C biomass was quite low.
The correlation between chlorophyte-euglenophyte and cyanophyte abundances suggested by the strong correlation between chl $b$ and Zea (Fig. 5f) was not actually observed with microscopy $\left(p>0.18\right.$ and $r^{2}=0.06$ for the correlation between Chloro+Eugleno-C and Cyano-C). It could be due to possible inclusion of some chlorophytes into small flagellates at some stations, such as Stns 9 and 31 (Figs. 7d,f \& 8) and/or contribution of picoplanktonic cyanobacteria to the $\mathrm{C}$ biomass of cyanophytes, which was not considered in this study.

\section{C:chl a ratio}

The average $\mathrm{C}$ :chl a ratio of total phytoplankton was $20 \pm 7$ in the present investigation. If the equations providing the highest estimation of $\mathrm{C}$ for diatoms and cryptophytes are taken into account, this ratio could be interpreted as $28 \pm 10$ (see also 'Results'). This ratio varies highly in nature, depending on light and nutrient status of phytoplankton species and groups (Cullen 1982). Harrison et al. (1977) reported variation from 20 to 60 in healthy cells. According to the modelling study of Cloern et al. (1995), which also compared the results of phytoplankton cultures under different light, temperature and nutrient conditions (a total of 219 published measurements), C:chl a ratios ranged between $\sim 18$ and $\sim 333$. The ratio found in the present study is at the lower end of the ranges reported previously (Table 6). It is not possible to estimate exact $\mathrm{C}$ values of phytoplankton species using $C: V$ conversion equations, due to variations in this ratio depending on phytoplankton species, growth conditions and cell sizes (Verity et al. 1992, Montagnes et al. 1994, Llewellyn \& Gibb 2000). For instance, C biomass of the diatom Actinocyclus subtilis was found to be 5 times higher with elemental $\mathrm{C}$ analysis than its $\mathrm{C}$ estimated from $V$ using the equation of Strathmann (1967) (Llewellyn \& Gibb 2000, Llewellyn et al. 2005). In addition, a 2 to 4 -fold difference in $\mathrm{C}$ cell quotas was reported for the same laboratory cultures with remarkably similar $V$ measured using the same $\mathrm{C}$ measurement technique, with an elemental C analyser (Verity et al. 1992, Montagnes et al. 1994). An inverse relationship between the cell $V(\sim 10$

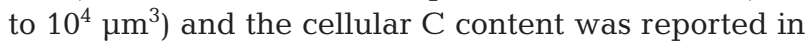
previous studies (i.e. big cells have lower C density than small cells) (Verity et al. 1992, Llewellyn \& Gibb 2000). C: $V$ conversion equations, which were used in the present study and established by Strathmann (1967), Verity et al. (1992), Montagnes et al. (1994), Menden-Deuer \& Lessard (2000) and Montagnes \& Franklin (2001), involve the range of cell $V$ found in our investigation (10 to $10^{5} \mu^{3}$ ). High cellular chl a content of dominant phytoplankton species could be an alternative hypothesis for low C:chl a ratios found in the re- 
Table 6. C:chl a ratios of total phytoplankton, dinoflagellates (Dino) and diatoms (Diat) in different environments and in cultures, given as mean $( \pm \mathrm{SD})$ and/or range. (-) Not given. Carbon estimation is from cell volumes using equations of (1) Strathmann (1967); (2) Verity et al. (1992); (3) Mullin et al. (1966); (4) Putt \& Stoecker (1989); (5) Søndergaard et al. 1991; (6) Montagnes et al. (1994). In the laboratory cultures, carbon estimation was made by a CHN analyzer

\begin{tabular}{|lccccl|}
\hline Region & Total & Dino & Diat & C-estimation & Source \\
\hline Southern Baltic & $20 \pm 7$ & $30 \pm 17$ & $9 \pm 7$ & $(1,2)$ & Present study \\
Mesocosm, Isefjord, Denmark & - & 6 & $50-100$ & $(1,3)$ & Havskum et al. (2004) \\
English Channel & $23-78$ & 666 & $10-48$ & $(1,2)$ & Llewellyn et al. (2005) \\
Iberian Poleward Current, Spain & $161-303$ & 32 & $79-250$ & $(1,2,4)$ & Rodríguez et al. (2006) \\
Mesocosm, Denmark and Norway & 24 & - & - & $(3,5)$ & Schlüter \& Havskum (1997) \\
Southern Ocean & $45-90$ & - & - & $(6)$ & Abraham et al. (2000) \\
Laboratory cultures & & 106 & 34 & CHN & Chan (1980) \\
Laboratory cultures & & $365-4800$ & $91-1749$ & CHN & Eker-Develi et al. (2006b) \\
Laboratory cultures & & $21-49$, & $18 \pm 4$, & CHN & Geider et al. (1997) and \\
& & & $14-28$ & & references therein \\
Laboratory cultures & & & $18-336$ & CHN & Laws \& Bannister (1980) \\
Laboratory cultures & & & $20-800$ & CHN & Sakshaug et al. (1989) \\
\hline
\end{tabular}

gion. Based on a 5 yr sampling study, Wasmund et al. (2001) reported that the peak chl a concentration (57 $\mu \mathrm{g}$ $\mathrm{l}^{-1}$ ) was found during a dinoflagellate bloom in the Lithuanian coastal waters in May 1993. Phytoplankton biomass (wet wt) corresponding to this peak chl a concentration was $16100 \mu \mathrm{g} \mathrm{l}^{-1}$ and $93 \%$ of this biomass was formed by the dinoflagellate Peridinella catenata (I. Olenina pers. comm.), which was also the dominant species in the present investigation in the Gotland Sea. If this biomass is roughly converted to $\mathrm{C}$ biomass by multiplying by 0.11 (Mullin et al. 1966), Phyto-C is found as $1770 \mu \mathrm{g} \mathrm{l}^{-1}$, resulting in a C:chl a ratio of 31, which is similar to our $\mathrm{C}$ :chl a ratio for dinoflagellates (Table 6). Using the same C conversion factor (0.11) in April 1999 in the Bight of Gdańsk, Stoń et al. (2002) found that the C:chl a ratio was even lower ( 22) for the wet wt $7898 \mu \mathrm{g} \mathrm{l}^{-1}$ and chl $a \sim 40 \mu \mathrm{g} \mathrm{l}^{-1}$. In that study as well, $P$. catenata was the dominant species, forming $\sim 97 \%$ of the total wet wt.

It is known that nutrient limitation promotes an increase in the C:chl a ratio (Harrison et al. 1977, Laws \& Bannister 1980, Sakshaug et al. 1989, Eker-Develi et al. 2006b). Simultaneous data on nutrients, pigments and phytoplankton cell counting were not available for the present study. However, based on nutrient measurements performed by the Institute of Meteorology and Water Management (IMGW 2005) 1 to 3 wk prior to our sampling (i.e. 4 to 8 April 2005), and phytoplankton $\mathrm{C}$ biomass estimated in the present investigation, we assume that nutrient limitation could be an issue along the central Polish coast $(\sim 0.1 \mu \mathrm{M}$ nitrate, $0.45 \mu \mathrm{M}$ phosphate and $8 \mu \mathrm{M}$ silicate) and in the Pomeranian Bight ( $>16.0 \mu \mathrm{M}$ nitrate, $0.3 \mu \mathrm{M}$ phosphate, $34 \mu \mathrm{M}$ silicate), while this was less probable in the southeastern Gotland Sea $(0.75 \mu \mathrm{M}, 0.6 \mu \mathrm{M}, 15 \mu \mathrm{M})$ and in the Bight of Gdańsk (70.0 $\mu \mathrm{M}$ nitrate, $1.2 \mu \mathrm{M}$ phosphate, $70 \mu \mathrm{M}$ silicate). Relatively high ratios of C:chl a were ob- served along the central Polish coast and in the Pomeranian Bight (Stns 18 through 27, Fig. 2), with respect to the Bight of Gdańsk (Stns 1 through 11 and 31 ), which could be related to nutrient distribution.

There was no clear relationship between C:chl a ratio and the average irradiance within the surface mixed layer in the present study (Fig. 10), whereas Llewellyn et al. (2005) observed a positive correlation between C:chl a ratios and log of $I_{\mathrm{SML}}$ in the English Channel among $2 \mathrm{yr}$ of weekly samples collected on clear sky days. Our observed C:chl a ratios were lower than our optimal C:chl a ratios, which were found using the phytoplankton acclimation models of Geider et al. (1997) and Blackford et al. (2004) (Fig. 10). These models were used by Llewellyn et al. (2005) and their observed C:chl a ratios for assimilation rates 1 to $3 \mathrm{~d}^{-1}$ were also below the model-derived $\mathrm{C}$ :chl a ratios, but higher than our observed C:chl a ratios (Fig. 10). Obviously, such a formulation of the relationship between irradiance and C:chl a did not take into account the light history of phytoplankton cells, but was only an instantaneous representation. It is also worth noting that according to Geider et al. (1997), estimates of $\mathrm{C}$ :chl a ratios based on their model might not accurately reflect the ratios of field populations because of substantial inter-specific variability in maximum growth rates, maximum chl a contents and light absorption characteristics of phytoplankton.

As expected, the $\mathrm{C}$ :chl a ratio here was higher for dinoflagellates $(30 \pm 17)$ than for diatoms $(9 \pm 7$ and $18 \pm 14$ when equations of Strathmann 1967 and Montagnes \& Franklin 2001 were used, respectively). This finding is in qualitative agreement with differences reported by Chan (1980) for diatom and dinoflagellate cultures, and by Llewellyn et al. (2005) for in situ observations. In contrast, Rodriguez et al. (2006) and Havskum et al. (2004) noted much higher C:chl a for 
diatoms than for dinoflagellates (Table 6). They noted that several factors could have caused these DiatC:Diat-chl a ratios to be higher than Dino-C:Dino-chl a ratios, such as (1) the decrease in chl a content of diatoms in the late growth phase; $(2)$ the dominance of large-celled diatoms with lower cellular chl a density; (3) the underestimation of Dino-C by microscopy; or (4) the decrease in chl a content of diatoms with increased light intensities.

\section{CONCLUSION}

The use of CHEMTAX together with the measured concentrations of marker pigments was quite successful for deriving biomass distribution of dominant phytoplankton groups in the southern Baltic Sea. Phytoplankton species composition and spatial distribution obtained from microscopy were similar to what was reported in previous years (Gasiunaite et al. 2005, Wasmund et al. 2005). It was observed that Peri, Ddx and chl $C_{1}+C_{2}$ concentrations were closely related to the $\mathrm{C}$ biomass of the dominant phytoplankton group, dinoflagellates, at the majority of stations. Excluding the phototrophic ciliate Mesodinium rubrum from cryptophyte biomass led to an important disagreement between microscopic biomass estimation and CHEMTAX-allocated chl a with this phytoplankton group.

In a few cases, the diatom contribution was overestimated by CHEMTAX analysis, probably due to the contribution of some small flagellates containing fucoxanthin, indicating the necessity of simultaneous microscopic analysis with pigment measurements.

Chl $\mathrm{a}$ and $\mathrm{C}$ biomass of minor phytoplankton groups were either not correlated significantly $(p>0.05$ for euglenophytes) or poorly correlated $\left(\mathrm{r}^{2}=0.2, \mathrm{p}<0.05\right.$ for chlorophytes). The possible reasons could be linked to uncertainties with CHEMTAX when dealing with minor pigments in low concentrations (e.g. chl $b$, Zea), the difficulties in classifying small flagellates by microscopy, and the possible influence of phototrophic grazers on some of these minor groups. Even though cyanophytes were also among the minor phytoplankton groups, there was a relatively good correlation between their marker pigment zeaxanthin and their $\mathrm{C}$ biomass, mainly due to 2 high values.

Successive runs of CHEMTAX using the output of pigment ratios from each run as the input for the next provided a convergence of ratios for only major phytoplankton groups. Accordingly, resulting Peri:chl $a$ and Fuco:chl a ratios of dinoflagellates and diatoms were $0.452 \pm 0.02$ and $0.489 \pm 0.03$, respectively, for our Baltic Sea samples. However, such a convergence was not observed in any of the pigment ratios of minor phytoplankton groups.
The estimated C:chl a ratio of total phytoplankton $(20 \pm 7)$ in the Baltic Sea was at the lower end of previously reported ratios, which might be a characteristic of dominant species in the study region during spring. However, possible changes in the C: $V$ ratio with varying size and species compositions is an issue which must be cautiously considered when presenting these ratios. C:chl a ratio was increased to $28 \pm 10$ upon usage of different $\mathrm{C}: V$ conversion equations.

Acknowledgements. This work has been supported by the JRC-European Commission. We acknowledge colleagues of the IOPAS, the Captain and the crew of the RV 'Oceania' for their support during the measuring campaign; E Lysiak-Pastuszak and IMGW for providing us their nutrient data; I. Olenina (Centre of Marine Research, Taikos, Klaipeda, Lithuania) for supplying us with phytoplankton carbon biomass data from 1993; and Drs. A. S. Heiskanen and A. C. Cardoso from JRC Ispra for allowing us to use their microscope. We are grateful to M. Dowell for early comments on the manuscript and to J. Challis for English corrections.

\section{LITERATURE CITED}

Abraham ER, Law CS, Boyd PW, Lavender SJ, Maldonado MT, Bowie AR (2000) Importance of stirring in the development of an iron-fertilized phytoplankton bloom. Nature 407:727-730

Alvain S, Moulin C, Dandonneau Y, Bréon FM (2005) Remote sensing of phytoplankton gruops in case 1 waters from global SeaWiFS imagery. Deep-Sea Res I 52:1989-2004

Blackford JC, Allen JI, Gilbert FJ (2004) Ecosystem dynamics at six contrasting sites: a generic modelling study. J Mar Syst 52:191-215

Bralewska JM, Witek Z (1995) Heterotrophic dinoflagellates in the ecosystem of the Gulf of Gdańsk. Mar Ecol Prog Ser $117: 241-248$

Chan AT (1980) Comparative physiological study of marine diatoms and dinoflagellates in relation to irradiance and cell size. II. Relationship between photosynthesis, growth and carbon-chlorophyll a ratio. J Phycol 16:428-432

Claustre H, Hooker SB, Van Heukelem L, Berthon JF and others (2004) An intercomparison of HPLC phytoplankton pigment methods using in situ samples: application to remote sensing and database activities. Mar Chem 85: $41-61$

Cloern JE, Grenz C, Vidergar-Lucas L (1995) An empirical model of the phytoplankton chlorophyll:carbon ratio - the conversion factor between productivity and growth rate. Limnol Oceanogr 40:1313-1321

Cullen JJ (1982) The deep chlorophyll maximum: comparing vertical profiles of chlorophyll a. Can J Fish Aquat Sci 39: 791-803

Demers S, Roy S, Gagnon R, Vignault C (1991) Rapid lightinduced changes in cell fluorescence and in xanthophyllcycle pigments of Alexandrium excavatum (Dinophyceae) and Thalassiosira pseudonana (Bacillariophycea): photoprotection mechanism. Mar Ecol Prog Ser 76:185-193

> Eker-Develi E, Kideys AE, Tugrul S (2006a) Role of Saharan dust on phytoplankton dynamics in the northeastern Mediterranean. Mar Ecol Prog Ser 314:61-75

Eker-Develi E, Kideys AE, Tugrul S (2006b) Effect of nutrients on culture dynamics of marine phytoplankton. Aquat Sci 68:28-39 
Gasiunaite ZR, Cardoso AC, Heiskanen AS, Henriksen P and others (2005) Seasonality of coastal phytoplankton in the Baltic Sea: influence of salinity and eutrophication. Estuar Coast Shelf Sci 65:239-252

Geider RJ, MacIntyre HL, Kana TM (1997) Dynamic model of phytoplankton growth and acclimation: responses of the balanced growth rate and the chlorophyll a:carbon ratio to light, nutrient-limitation and temperature. Mar Ecol Prog Ser 148:187-200

Gustafson DE Jr, Stoecker DK, Johnson MD, Van Heukelem WF, Sneider K (2000) Cryptophyte algae are robbed of their organelles by the marine ciliate Mesodinium rubrum. Nature 405:1049-1052

- Harrison PJ, Conway HL, Holmes RW, Davis CO (1977) Marine Diatoms grown in chemostats under silicate or ammonium limitation. III. Cellular chemical composition and morphology of Chaetoceros debilis, Skeletonema costatum, and Thalassiosira gravida. Mar Biol 43:19-31

Havskum H, Schlüter L, Scharek R, Berdalet E, Jacquet S (2004) Routine quantification of phytoplankton groups-microscopy or pigment analyses? Mar Ecol Prog Ser 273: 31-42

HELCOM (1996) Third periodic assessment of the state of the marine environment of the Baltic Sea, 1989-1993. Background Document, Baltic Sea Environ Proc 64B

- Henriksen P, Riemann B, Kaas H, Sorensen HM, Sorensen HL (2002) Effects of nutrient-limitation and irradiance on marine phytoplankton pigments. J Plankton Res 24:835-858

Hooker SB, Claustre H, Ras J, Van Heukelem L and others (2000) The first SeaWiFS HPLC analysis round-robin experiment (SeaHARRE-1). In: Hooker SB, Firestone ER (eds) NASA Tech Memo. 2000-206892, vol. 14. NASA Goddard Space Flight Center, Greenbelt, MD, p 1-42

IMGW (2005) Monitoring cruise report of R/V Baltica in the Polish sector of the southern Baltic Sea on 4-8 April 2005. Institute of Meteorology and Water Management, Maritime Branch, Gdynia

Irigoien X, Meyer B, Harris R, Harbour D (2004) Using HPLC pigment analysis to investigate phytoplankton taxonomy: the importance of knowing your species. Helgol Mar Res $58: 77-82$

Janson S (2004) Molecular evidence that plastids in the toxinproducing dinoflagellate genus Dinophysis originate from the free-living cryptophyte Teleaulax amphioxeia. Environ Microbiol 6:1102-1106

Jeffrey SW, Vesk M (1997) Introduction to marine phytoplankton and their pigment signatures. In: Jeffrey SW, Mantoura RFC, Wright SW (eds) Phytoplankton pigments in oceanography: guidelines to modern methods, UNESCO monographs on oceanographic methodology no. 10. UNESCO, Paris, p 37-85

Johnsen G, Sakshaug E (1993) Bio-optical characteristics and photoadaptive responses in toxic and bloom-forming dinoflagellates Gyrodinium aureolum, Gymnodinium galatheanum, and two strains of Prorocentrum minimum. J Phycol 29:627-642

Joint Global Ocean Flux Study (1994) Protocols for the joint global ocean flux study core measurements. Intergovernmental Oceanographic Commission. SCOR. Manual and Guides, UNESCO 29:91-96

Kim JS, Jeong HJ (2004) Feeding by the heterotrophic dinoflagellates Gyrodinium dominans and G. spirale on the red-tide dinoflagellate Prorocentrum minimum. Mar Ecol Prog Ser 280:85-94

Kovala PE, Larrance JD (1966) Computation of phytoplankton cell numbers, cell volumes, cell surface and plasma volume volume per litre from microscopial counts. Univ Wash Publ Oceanogr 38:1-21
Kowalczuk P, Olszewski J, Darecki M, Kaczmarek S (2005) Empirical relationships between coloured dissolved organic matter (CDOM) absorption and apparent optical properties in Baltic Sea waters. Int J Remote Sens 26:345-370

Latasa M (2007) Improving estimations of phytoplankton class abundances using CHEMTAX. Mar Ecol Prog Ser 329:13-21

Laws EA, Bannister TT (1980) Nutrient- and light-limited growth of Thalassiosira fluviatilis in continuous culture with implications for phytoplankton growth in the ocean. Limnol Oceanogr 25:457-473

Llewellyn CA, Gibb SW (2000) Intra-class variability in the carbon, pigment and biomineral content of prymnesiophytes and diatoms. Mar Ecol Prog Ser 193:33-44

Llewellyn CA, Fishwick JR, Blackford JC (2005) Phytoplankton community assemblage in the English Channel: a comparison using chl a derived from HPLC-CHEMTAX and carbon derived from microscopy cell counts. J Plankton Res 27:103-119

> Mackey MD, Mackey DJ, Higgins HW, Wright SW (1996) CHEMTAX - a program for estimating class abundances from chemical markers: application to HPLC measurements of phytoplankton. Mar Ecol Prog Ser 144:265-283

Mantoura RFC, Llewellyn CA (1983) The rapid determination of algal chlorophyll and carotenoid pigments and their breakdown products in natural waters by reverse-phase high performance chromatography. Anal Chim Acta 151: 297-314

Menden-Deuer S, Lessard EJ (2000) Carbon to volume relationships for dinoflagellates, diatoms, and other protist plankton. Limnol Oceanogr 45:569-579

- Meyer-Harms B, Pollehne F (1998) Alloxanthin in Dinophysis norvegica (Dinophysiales, Dinophyceae) from the Baltic Sea. J Phycol 34:280-285

Montagnes DJS, Franklin DJ (2001) Effect of temperature on diatom volume, growth rate, and carbon and nitrogen content: reconsidering some paradigms. Limnol Oceanogr 46:2008-2018

Montagnes DJS, Berges JA, Harrison PJ, Taylor FJR (1994) Estimating carbon, nitrogen, protein, and chlorophyll a from volume in marine phytoplankton. Limnol Oceanogr 39:1044-1060

> Mouritsen L, Richardson K (2003) Vertical microscale patchiness in nano- and microplankton distribution in a stratified estuary. J Plankton Res 25:783-797

Mullin MM, Sloan PR, Eppley PW (1966) Relationship between carbon content, cell volume, and area in phytoplankton. Limnol Oceanogr 11:307-311

Olenina I, Hajdu S, Edler L, Andersson A and others (2006) Biovolumes and size-classes of phytoplankton in the Baltic Sea. HELCOM Baltic Sea Environ Proc 106

Piippola S, Kononen K (1995) Pigment composition of phytoplankton in the Gulf of Bothnia and Gulf of Finland. Aqua Fenn 25:39-48

Putt M, Stoecker DK (1989) An experimentally determined carbon:volume ratio for marine 'oligotrichous' ciliates from estuarine and coastal waters. Limnol Oceanogr 34: 1097-1103

Rodríguez F, Varela M, Zapata M (2002) Phytoplankton assemblages in the Gerlache and Bransfield Straits (Antarctic Peninsula) determined by light microscopy and CHEMTAX analysis of HPLC pigment data. Deep-Sea Res II 49:723-747

Rodríguez F, Garrido JL, Crespo BG, Arbones B, Figueiras FG (2006) Size-fractionated phytoplankton pigment groups in the NW Iberian upwelling system: impact of the Iberian Poleward Current. Mar Ecol Prog Ser 323:59-73 
Rychert K (2004) The size structure of the Mesodinium rubrum population in the Gdańsk Basin. Oceanologia 46:439-444

Sakshaug E, Andresen K, Kiefer DA (1989) A steady state description of growth and light absorption in the marine planktonic diatom Skeletonema costatum. Limnol Oceanogr 34:198-205

Schlüter L, Havskum H (1997) Phytoplankton pigments in relation to carbon content in phytoplankton communities. Mar Ecol Prog Ser 155:55-65

Schlüter L, Møhlenberg F (2003) Detecting presence of phytoplankton groups with non-specific pigment signatures. J Appl Phycol 15:465-476

Schlüter L, Møhlenberg F, Havskum H, Larsen S (2000) The use of phytoplankton pigments for identifying and quantifying phytoplankton groups in coastal areas: testing the influence of light and nutrients on pigment/chlorophyll $a$ ratios. Mar Ecol Prog Ser 192:49-63

Sokal RR, Rohlf FJ (2000) Biometry: the principles and practice of statistics in biological research, 3rd edn. WH Freeman \& Co, New York

Søndergaard M, Jensen LM, Ærtebjerg G (1991) Picoalgae in Danish coastal waters during summer stratification. Mar Ecol Prog Ser 79:139-149

Sournia A, Belin C, Billard C, Martial C and others (1992) The repetitive and expanding occurrence of a green, bloom forming dinoflagellate (Dinophyceae) on the coasts of France. Cryptogam Algol 13:1-13

Stoń J, Kosakowska A, Łotocka M, Łysiak-Pastuszak E (2002) Pigment composition in relation to phytoplankton community structure and nutrient content in the Baltic Sea. Oceanologia 44:419-437

Strathmann RR (1967) Estimating the organic carbon content of phytoplankton from cell volume or plasma volume. Limnol Oceanogr 12:411-418

Tester PA, Geesey ME, Guo C, Paerl HW, Millie DF (1995) Evaluating phytoplankton dynamics in the Newport River estuary (North Carolina, USA) by HPLC-derived pigment profiles. Mar Ecol Prog Ser 124:237-245

Uitz J, Claustre H, Morel A, Hooker S (2006) Vertical distribution of phytoplankton communities in open ocean: an

Editorial responsibility: Howard Browman,

Storebø, Norway assessment based on surface chlorophyll. J Geophys Res 111:C08005

Veldhuis MLW, Kraay GW (2004) Phytoplankton in the subtropical Atlantic Ocean: towards a better assessment of biomass and composition. Deep-Sea Res I 51:507-530

Verity PG, Robertson CY, Tronzo CR, Andrews MG, Nelson JR, Sieracki ME (1992) Relationships between cell volume and the carbon and nitrogen content of marine photosynthetic nanoplankton. Limnol Oceanogr 37: 1434-1446

- Vidussi F, Claustre H, Manca BB, Luchetta A, Marty JC (2001) Phytoplankton pigment distribution in relation to the upper thermocline circulation in the Eastern Mediterranean Sea during winter. J Geophys Res 106: 19939-19956

> Wänstrand I, Snoeijs P (2006) Seasonal phytoplankton pigment dynamics in the northern Baltic Sea: Assessment by ships-of-opportunity. Estuar Coast Shelf Sci 66:135-146

Wasmund N, Nausch G, Matthäus W (1998) Phytoplankton spring blooms in the southern Baltic Sea-spatiotemporal development and long-term trends. J Plankton Res 20:1099-1117

Wasmund N, Nausch G, Postel L, Witk Z and others (2000) Trophic status of coastal and open areas of the south-eastern Baltic Sea based on nutrient and phytoplankton data from 1993-1997. Meereswiss Ber Warnemünde 38:1-83

> Wasmund N, Andrushaitis A, Łysiak-Pastuszak E, MüllerKarulis B and others (2001) Trophic status of the southeastern Baltic Sea: A comparison of coastal and open areas. Estuar Coast Shelf Sci 53:849-864

Wasmund N, Pollehne F, Postel L, Siegel H, Zettler M (2005) Biologische Zustandseinschätzung der Ostsee im Jahre 2004. Meereswiss. Ber., No 64, Warnemünde, p 1-78

Witek M (1998) Annual changes of abundance and biomass of planktonic ciliates in the Gdańsk Basin, southern Baltic. Int Rev Hydrobiol 83:163-182

Wright SW, Jeffrey SW, Mantoura FC, Llewellyn CA, Bjørnland T, Repeta D, Welschmeyer N (1991) Improved HPLC method for the analysis of chlorophylls and carotenoids from marine phytoplankton. Mar Ecol Prog Ser 77: 183-196

Submitted: July 17, 2007; Accepted: November 4, 2007 Proofs received from author(s): April 7, 2008 